\title{
Application of Surface Geophysical Techniques In a Study of the Geomorphology of the Lower Copper River, Alaska
}

By Timothy P.Brabets

U.S. GEOLOGICAL SURVEY

Water-Resources Investigations Report 94-4165

Prepared in cooperation with the

ALASKA DEPARTMENT OF TRANSPORTATION

AND PUBLIC FACILITIES

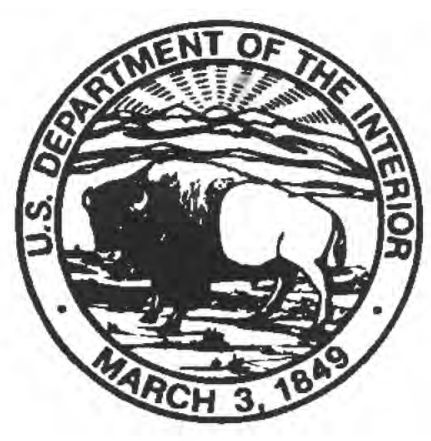

Anchorage, Alaska

1995. 


\section{U.S. DEPARTMENT OF THE INTERIOR \\ BRUCE BABBITT, Secretary}

U.S. GEOLOGICAL SURVEY

Gordon P. Eaton, Director

For additional information write to:

District Chief

U.S. Geological Survey

4230 University Drive, Suite 201

Anchorage, Alaska 99508-4664
Copies of this report may be purchased from:

\author{
U.S. Geological Survey \\ Earth Science Information Center \\ Open-File Reports Section \\ Box 25286, MS 517 \\ Denver Federal Center \\ Denver, Colorado 80225
}




\section{CONTENTS}

Abstract $\ldots \ldots \ldots \ldots \ldots \ldots \ldots \ldots \ldots \ldots \ldots \ldots \ldots \ldots \ldots \ldots \ldots \ldots \ldots \ldots \ldots \ldots \ldots \ldots, 1$

Introduction ............................................ 1

Location and description of the study area $\ldots \ldots \ldots \ldots \ldots \ldots \ldots \ldots \ldots \ldots \ldots, 3$

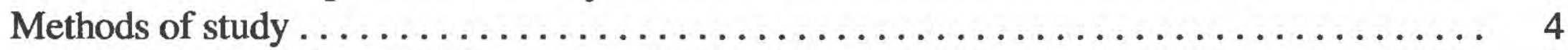

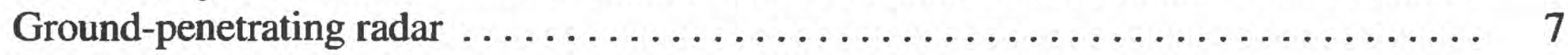

Continuous seismic reflection using a color fathometer................ 8

Continuous seismic reflection using a tuned transducer................ 8

Application of surface geophysical techniques ...................... 9

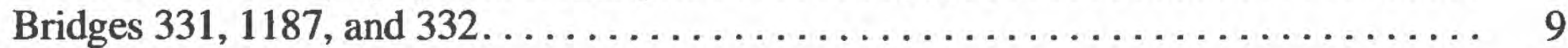

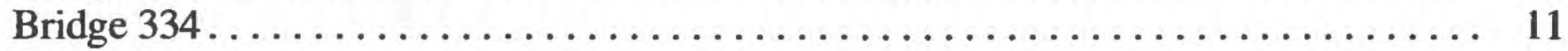

Bridge $342 \ldots \ldots \ldots \ldots \ldots \ldots \ldots \ldots \ldots \ldots \ldots \ldots \ldots \ldots \ldots \ldots \ldots \ldots \ldots \ldots \ldots \ldots \ldots, 12$

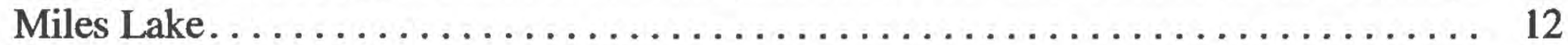

Summary and conclusions .................................... 13

References cited............................................ 14

\section{FIGURES}

1. Map showing the lower Copper River Delta .................. 2

2. Graph showing daily mean discharge of the Copper River at Million Dollar Bridge, 1992 water year ............................ 3

3. Map showing locations of bridges along the Copper River Highway ........ 5

4. Chart relating reflection configurations to the lithologic and stratigraphic properties of sediments in the glaciated northeast ................ 6

5. Photograph of airboat equipped with ground-penetrating radar........... 7

6. Diagram showing characteristics of seismic reflection sound sources......... 9

7-9. Plan views of:

7. Bridge 331 showing locations of geophysical profiles ............ 17

8. Bridge 1187 showing locations of geophysical profiles $\ldots \ldots \ldots \ldots \ldots \ldots 18$

9. Bridge 332 showing locations of geophysical profiles ............ 19

10-12. Generalized geologic cross sections at:

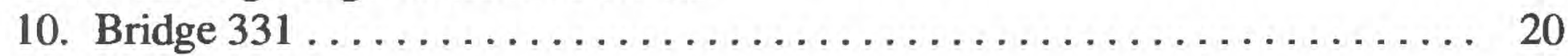

11. Bridge $1187 \ldots \ldots \ldots \ldots \ldots \ldots \ldots \ldots \ldots \ldots \ldots \ldots \ldots \ldots \ldots \ldots \ldots \ldots \ldots \ldots \ldots \ldots, 21$

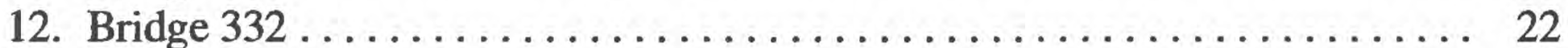

13. Cross sections of the Copper River, downstream side of Bridge 331........ 23

14. Record of a $100-\mathrm{mHz}$ ground-penetrating radar cross section and interpretation of infilled area at Bridge 331 near pier $3 \ldots \ldots \ldots \ldots \ldots .24$

15. Record of 7.0-kHz continuous seismic reflection and interpretation of infilled area at Bridge 331 near pier 1.................... 25

16. Cross sections of the Copper River, downstream side of Bridge $1187 \ldots \ldots \ldots 26$

17. Record of $300-\mathrm{mHz}$ ground-penetrating radar cross section from

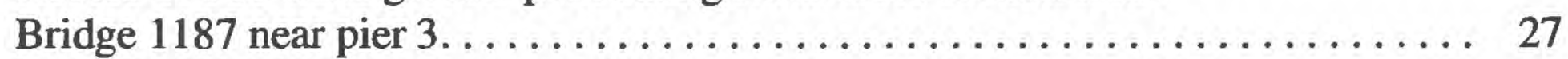

18. Record of 7.0-kHz continuous seismic reflection cross section from

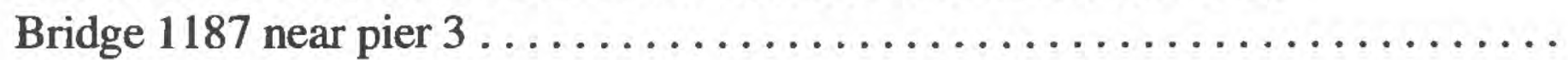


19. Cross sections of the Copper River, downstream side of Bridge $332 \ldots \ldots \ldots 29$

20-21. Records of 7.0-kHz continuous seismic reflection from:

20. A cross section from Bridge 332 near pier $1 \ldots \ldots \ldots \ldots \ldots \ldots .30$

21. Longitudinal profile near pier 1, Bridge $332 \ldots \ldots \ldots \ldots \ldots \ldots \ldots . \ldots \ldots$

22. Plan view of Bridge 334 showing location of ground-penetrating radar profile . . 32

23. Cross sections of the Copper River, downstream side of Bridge $334 \ldots \ldots \ldots . .33$

24. Record of $100-\mathrm{mHz}$ ground-penetrating radar cross section from Bridge $334 \ldots . .34$

25. Plan view of Bridge 342 showing locations of geophysical profiles . . . . . . . 36

26. Generalized geologic cross section at Bridge $342 \ldots \ldots \ldots \ldots \ldots \ldots \ldots \ldots \ldots$

27. Color fathometer record near upstream left spur dike at Bridge $342 \ldots \ldots \ldots \ldots 38$

28. Record of $300-\mathrm{mHz}$ ground-penetrating radar cross section from

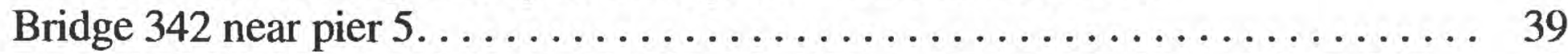

29. Record of $3.5-\mathrm{kHz}$ continuous seismic reflection cross section from Bridge 342 .. 40

30. Map showing Miles Lake in 1950 and $1985 \ldots \ldots \ldots \ldots \ldots \ldots \ldots \ldots . \ldots \ldots \ldots \ldots$

31. Diagram of borings from area near the Million Dollar Bridge............ 43

32-33: Records of 7.0-kHz continuous seismic reflection cross sections from:

32. Profile 1 at Miles Lake .......................... 44

33. Profile 2 at Miles Lake ........................ 46

\section{TABLE}

1. Data from Bridges 331, 1187, and 332 during open-water periods, 1991-92 ..... 10

CONVERSION FACTORS, ABBREVIATIONS, AND VERTICAL DATUM

\begin{tabular}{rll}
\hline Multiply & By & To obtain \\
\hline inch (in.) & 25.4 & millimeter \\
foot (ft) & 0.3048 & meter \\
mile (mi) & 1.609 & kilometer \\
square mile $\left(\mathrm{mi}^{2}\right)$ & 2.590 & square kilometer \\
cubic inch $\left(\mathrm{in}^{3}\right)$ & 16.39 & cubic centimeter \\
foot per nanosecond $(\mathrm{ft} / \mathrm{ns})$ & 0.3048 & meter per nanosecond \\
foot per second $(\mathrm{ft} / \mathrm{s})$ & 0.3048 & meter per second \\
cubic foot per second $\left(\mathrm{ft}^{3} / \mathrm{s}\right)$ & 0.02832 & cubic meter per second \\
ton per day (ton/d) & 0.9072 & megagram per day \\
\hline
\end{tabular}

Abbreviations used in this report:

$\mathrm{mg} / \mathrm{L}$, milligram per liter

$\mathrm{mHz}$, megahertz

$\mathrm{mm}$, millimeter

$\mathrm{kHz}$, kilohertz

National Geodetic Vertical Datum of 1929 (NGVD of 1929):

A geodetic datum derived from a general adjustment of the first-order level nets of both the United States and Canada, formerly called Sea Level Datum of 1929. 


\title{
Application of Surface Geophysical Techniques in a Study Of the Geomorphology of the Lower Copper River, Alaska
}

\author{
By Timothy P. Brabets
}

\begin{abstract}
As part of a geomorphology study of the lower Copper River, three surface geophysical techniques were tested for their ability to detect infilled scour holes at bridge piers, old river channels, and subbottom deposits in a glacier-formed lake. The methods were (1) ground-penetrating radar, (2) continuous seismic reflection using a color fathometer, and (3) continuous seismic reflection using a tuned transducer. Ground-penetrating radar detected infilled scour holes at bridge piers in water depths less than 20 feet and detected old river channels on land. Continuous seismic reflection using a tuned transducer was effective in water and detected infilled scour holes at bridge piers and subbottom deposits in a glacier lake. The color fathometer was useful in determining depths of water but was not able to penetrate the subbottom.
\end{abstract}

\section{INTRODUCTION}

Geophysical techniques have been used extensively for many years to map petroleum and mining deposits (Haeni, 1988a). In hydrologic investigations, surface geophysical techniques have been used to map lake deposits, to determine the depth to bedrock, to delineate leachate plumes from landfills, to map aquifers, and to determine water table configurations (Davis and Annan, 1989). In recent years, with advances in electronic equipment, new instruments, and computer processing programs, the use of geophysics in hydrologic studies is increasing (Haeni, 1986).

Surface geophysical methods can be used to detect physical or electrical property changes in subsurface materials or fluids. Selection of the appropriate geophysical method is determined by the penetration depths, desired resolution, and by the physical property changes in the subsurface materials. Typical properties measured are electrical conductivity, velocity of sound, gravity fields, and magnetic fields. Some knowledge of the physical properties of a subsurface material is needed for the successful interpretation of surface geophysical records.

One of the more recent uses of surface geophysical techniques has been in detecting infilled scour holes near bridge piers. In many instances, scour will occur at a bridge pier during a highwater period. The material near the pier will usually scour during the rising stages of high water, and then refill as the water stage recedes. Surveying after the high-water period generally will not reveal an infilled scour hole. Coring can yield accurate quantitative information, but the process is slow and expensive, and it generally does not provide a continuous profile. However, by using different geophysical methods and then correlating the best results, Gorin and Haeni (1989) were able to document past channel conditions. Crumrine (1991) also used these methods to locate and determine depths of infilled scour holes at 14 bridge sites in Oregon. 


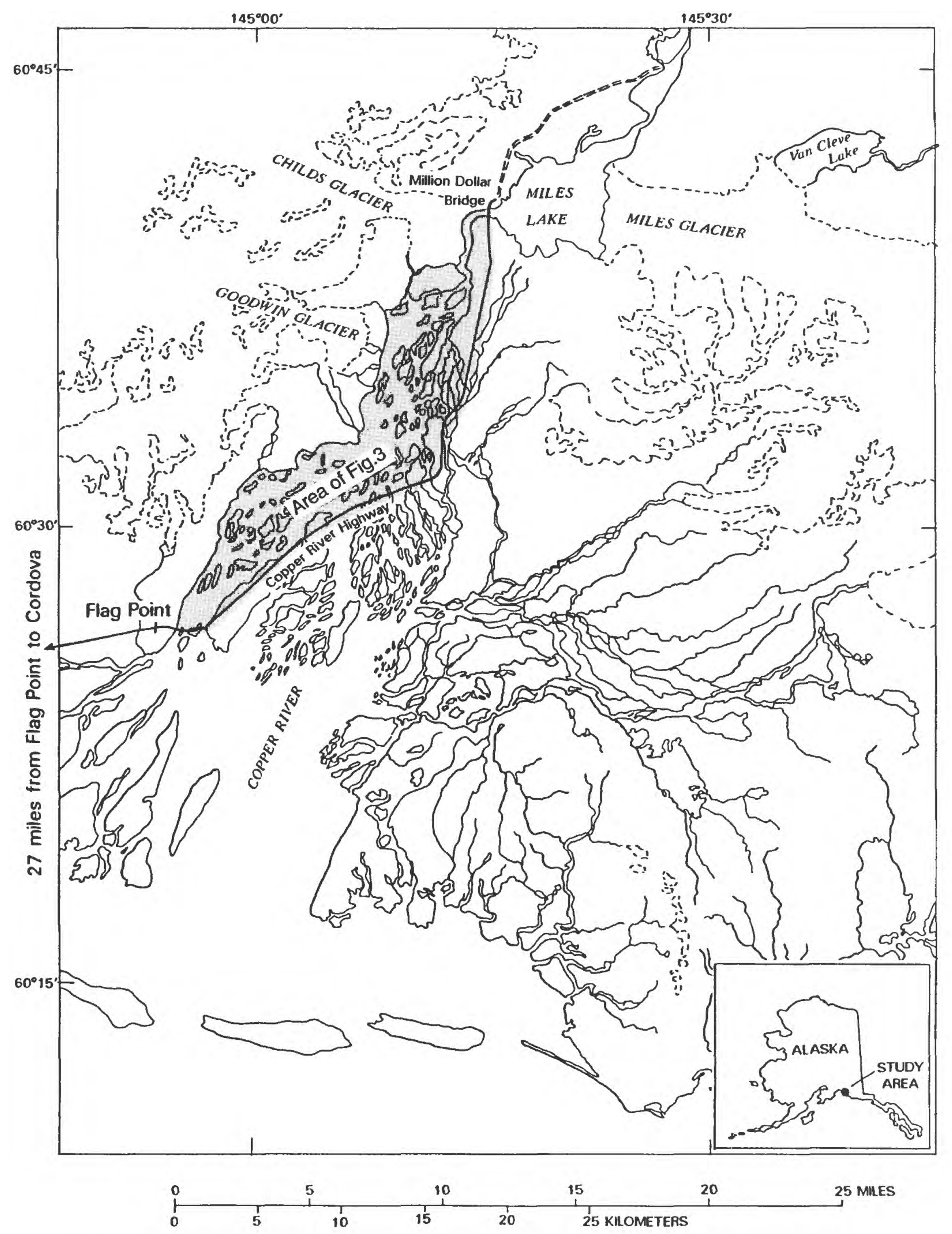

Figure 1. The lower Copper River Delta. 
In April 1991, under a cooperative agreement with the State of Alaska, Department of Transportation and Public Facilities (ADOT\&PF), the U.S. Geological Survey (USGS) began a study of the geomorphology of the lower Copper River. The study area encompasses the Copper River from Miles Lake to Flag Point on the Copper River Highway (fig. 1). As part of this study, some geophysical techniques were tested. The specific objectives were to determine if the geophysical techniques are useful in detecting infilled scour holes near bridge piers, the location of old stream channels, and the stratigraphy of lake deposits of a glacier-formed lake. This report describes the results of the field tests of the geophysical techniques.

\section{LOCATION AND DESCRIPTION OF THE STUDY AREA}

The lower Copper River, including the Copper River Delta (fig. 1) is a complex and dynamic system. Near its mouth, the river drains an area of approximately $24,000 \mathrm{mi}^{2}$, making it the sixth largest basin in the State of Alaska. The average discharge of the Copper River at the Million Dollar Bridge is about $63,000 \mathrm{ft}^{3} / \mathrm{s}$; minimum flows occur during winter months and maximum flows occur during summer months (fig. 2). During the open-water period (late May to mid-October), a high-flow period reflecting snowmelt runoff occurs in early July and a high-flow period reflecting rainfall runoff occurs in August. Glacier-dammed Van Cleve Lake (fig. 1) breaks out approximately every 7 years, causing a sharp and rapid increase in flow in the Copper River. The river transports large quantities of sediment from glaciers and erodible banks of the Copper River Lowlands located upstream of Miles Lake. Channels in the approximately 300-square-mile delta are constantly scoured and filled.

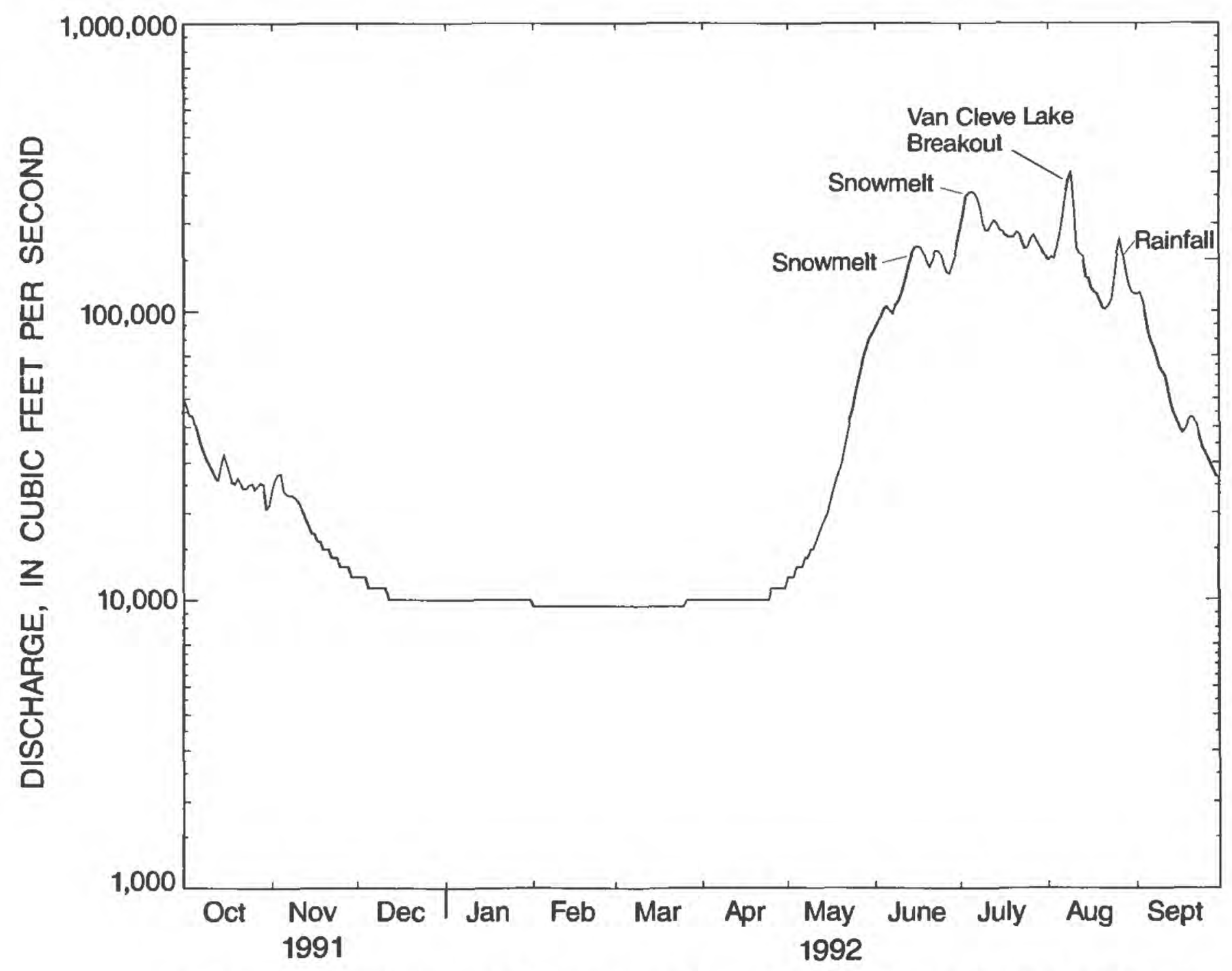

Figure 2. Daily mean discharge of the Copper River at Million Dollar Bridge, 1992 water year. 
The Copper River Highway was originally the railbed of the Copper River and Northwestern Railroad. Built in 1908-11 to haul copper ore from the Kennecott Mine in interior Alaska to Cordova, the railroad ceased operation in 1938. From 1938 to about 1962, the railroad bed was gradually converted to the Copper River Highway, beginning at Cordova and extending several miles past the Million Dollar Bridge. When the Alaska earthquake of 1964 struck, most, if not all, of the bridges along the highway were damaged beyond repair and work on extending the road was halted.

Reconstruction of the bridges between Flag Point (Mile 27) and the Million Dollar Bridge (Mile 48) began in 1970. At some locations along the highway where flow had shifted away from the road, bridges were not rebuilt; rather, the bridge opening was filled in. The north span of the Million Dollar Bridge, which had collapsed during the 1964 earthquake, was not raised but a replacement pier was constructed to stabilize the remaining spans. When construction was completed in 1978, 12 bridges (fig. 3) were located between Flag Point and the Million Dollar Bridge.

Since completion of the bridges, the channels of the Copper River have continued to scour and fill. In 1992, most of the discharge of the Copper River downstream from the Million Dollar Bridge flowed under four bridges: Bridge 331, Bridge 1187, Bridge 332, and Bridge 342 (Brabets, 1994). Flow through these four bridges accounts for more than 95 percent of the flow at the Million Dollar Bridge. Depths of flow vary at each bridge, ranging from less than $5 \mathrm{ft}$ to more than $30 \mathrm{ft}$. Velocities also vary at each bridge: velocities as high as $11 \mathrm{ft} / \mathrm{s}$ were measured at Bridges 331 and 342 .

During another phase of the geomorphology study, it was determined that channel scour has occurred at most of the bridges except at the Million Dollar Bridge (Brabets, 1994). The channel scour was due to constriction of channels near the bridges or to the long-term degradation/aggradation of the channel. Significant scour has occurred at Bridge 331 and at Bridge 342. Scour was so severe at Bridge 342 that the bridge was lengthened in 1987.

\section{METHODS OF STUDY}

For this study, three different surface geophysical techniques were evaluated: groundpenetrating radar, continuous seismic reflection using a color fathometer, and continuous seismic reflection using a tuned transducer. Multiple techniques were used because one technique may prove more effective than another, depending on the field condition.

In utilizing seismic techniques, the laws of physics that govern the propagation of sound are applied to infer the subsurface geology. In seismic reflection, a sound wave is generated by a sound source and travels down through the earth. When the sound wave encounters an interface between two materials, and if there is a contrast in the acoustic impedance (the product of the density and acoustic velocity of each material) of the two materials, some of the energy will be reflected. The angle of reflection is equal to the angle of incidence.

Ground-penetrating radar operates under much the same principles as seismic techniques, except that electromagnetic energy, rather than a sound wave, is transmitted into the subsurface. The reflected signal will depend on the dielectric and conductivity characteristics of the materials. Haeni (1988b) related some reflection configurations of radar records to the stratigraphic and litho-

logic properties of unconsolidated aquifers in the glaciated northeast (fig. 4). These basic relations also apply to this study area. 


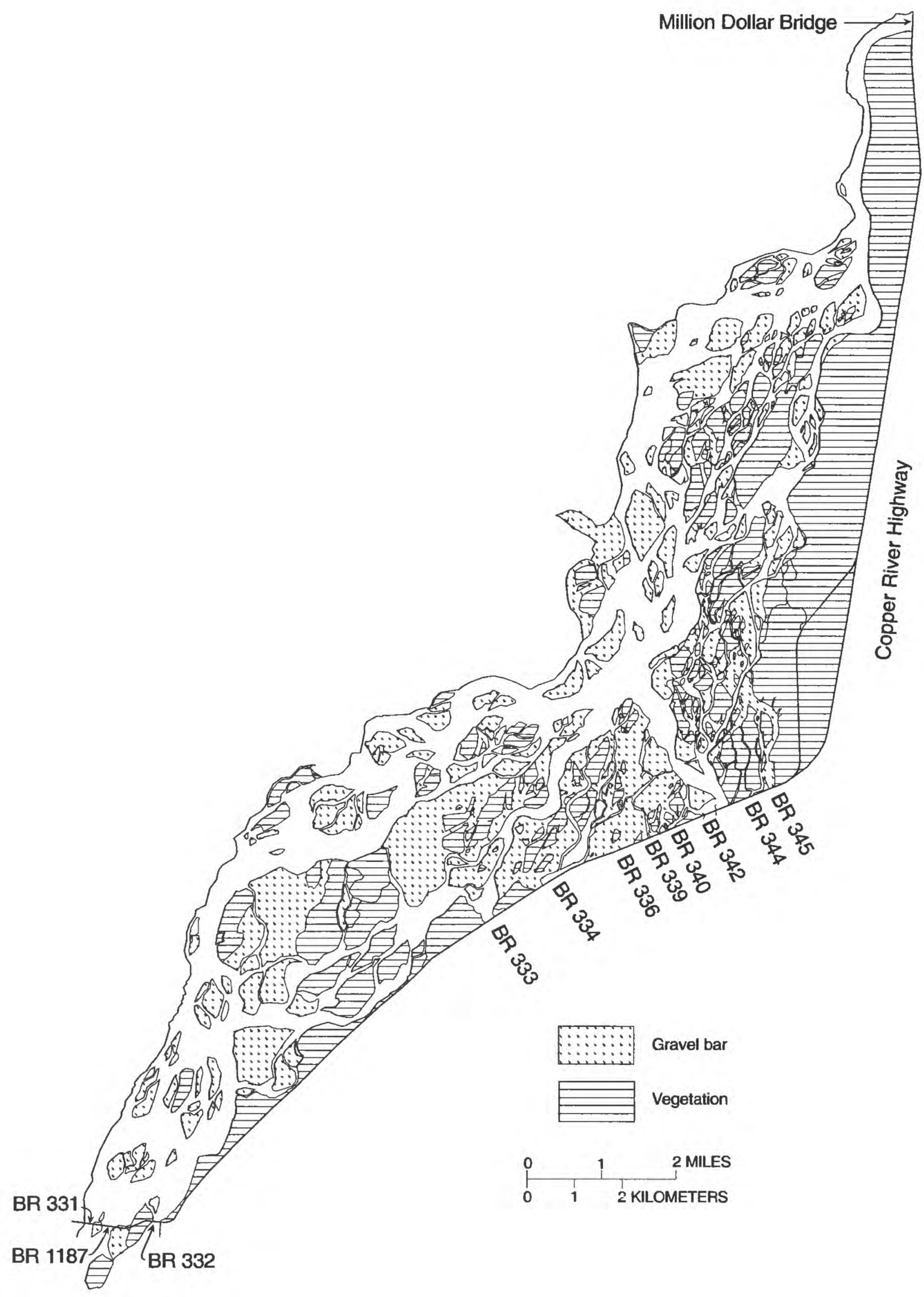

Figure 3. Locations of bridges (BR) along the Copper River Highway. 

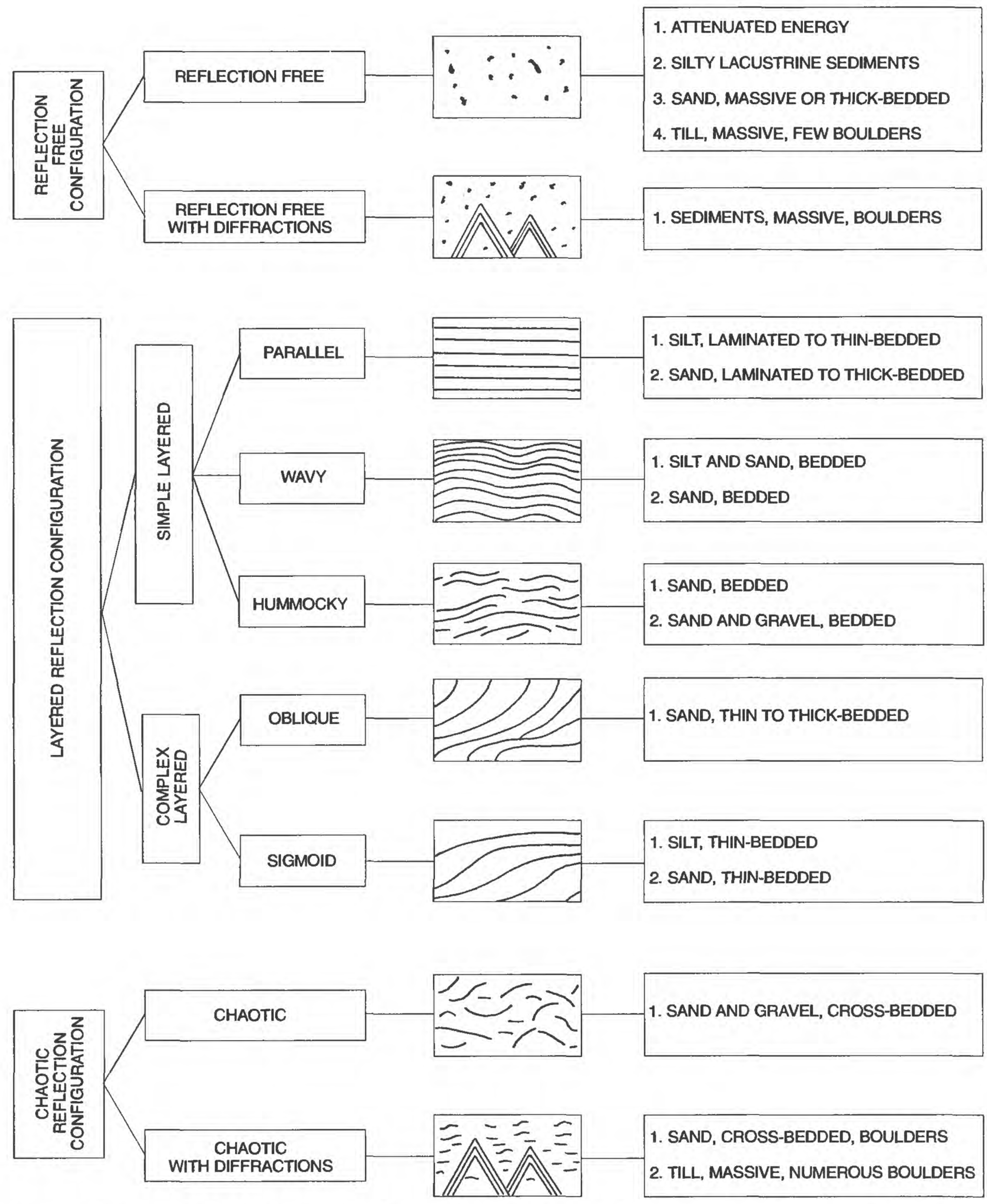

Figure 4. Chart relating reflection configurations to the lithologic and stratigraphic properties of sediments in the glaciated northeast (modified from Haeni, 1988b). 
All field work was done by use of an airboat (fig. 5). The airboat was the most reliable way to collect field data because it could easily maneuver through shallow water or around sandbars. In certain locations, primarily near piers, the velocity of the Copper River was relatively high. In these areas, no attempts were made to collect data.

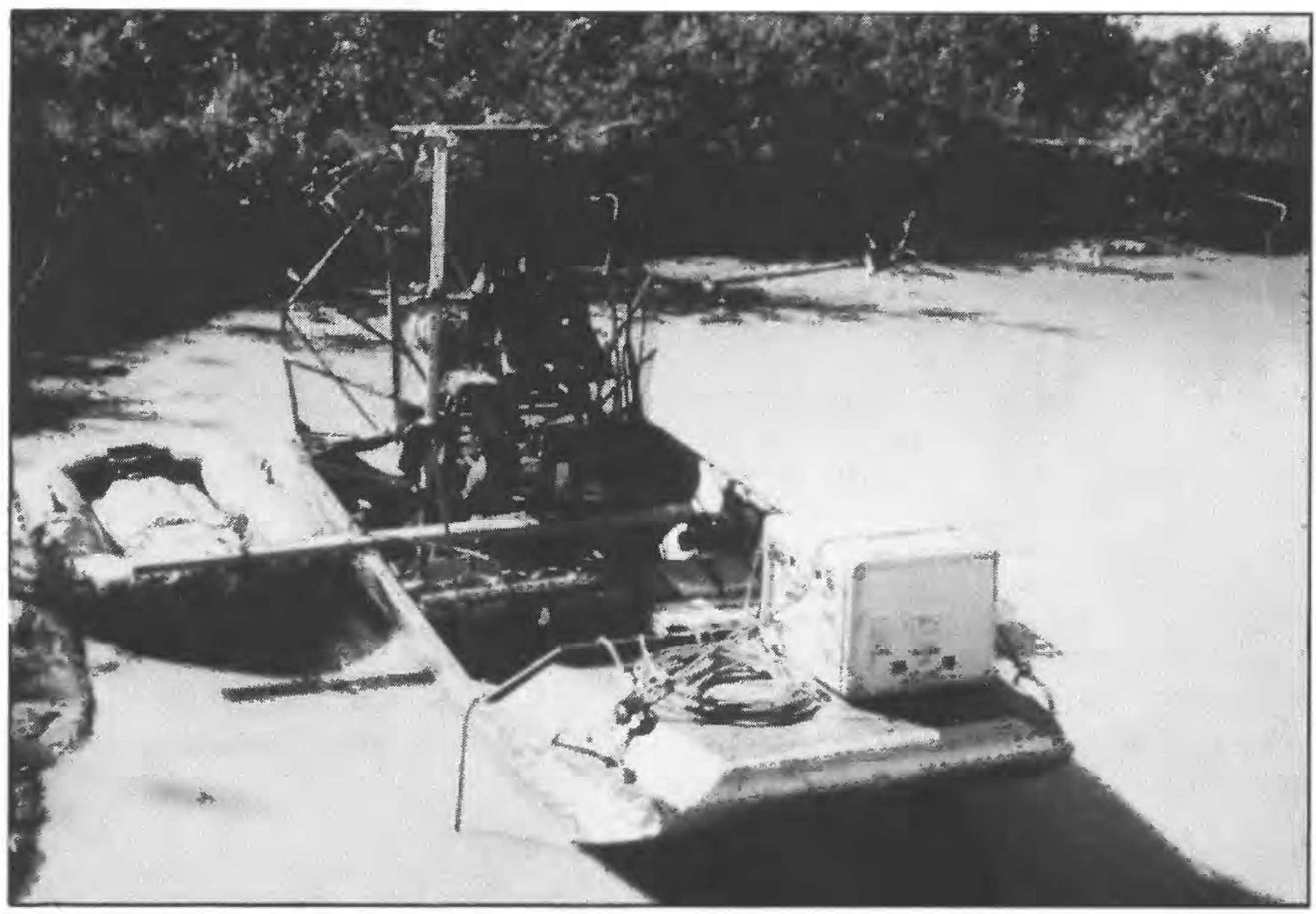

Figure 5. Airboat equipped with ground-penetrating radar.

In addition, a Hydro $\mathrm{I}^{1}$ positioning system was used in 1992 with the continuous seismic reflection/tuned transducer system to better define the location of the boat. The Hydro I is a shorebased electronic distance-measuring (EDM) instrument. A cone-shaped reflector head is mounted on the boat, which allows the EDM to track the boat. Digital sounding data and concurrent horizontal coordinate data were transmitted from the boat to a data logger on shore for later processing.

\section{Ground-Penetrating Radar}

In using ground-penetrating radar, 80 - to $1,000-\mathrm{mHz}$ (megahertz) electromagnetic pulses are sent to the subsurface by a transmitting antenna. Because of the differences in electrical properties of subsurface materials, different amounts of energy are reflected back to the surface, attenuated, or transmitted into deeper layers.

\footnotetext{
${ }^{1}$ The use of trade and firm names in this report is for identification purposes only and does not constitute endorsement by the U.S. Geological Survey.
} 
The reflected pulse received at the antenna is sent through a control unit where it can be plotted on a graphic recorder or stored on digital tape. The two-way travel time in nanoseconds $\left(10^{-9}\right.$ seconds) is displayed and recorded. Knowing the travel time and the relative dielectric permittivity of a given medium, the depth to each interface can be calculated (Beres and Haeni, 1991).

Ground-penetrating radar seldom penetrates more than $100 \mathrm{ft}$ into the subsurface (Wright and others, 1984) and in highly conductive material it may penetrate only a few feet (Olhoeft, 1984). Also, ground-penetrating radar is ineffective where sediments are saturated with or overlain by salt water. Fresh water also attenuates the radar signal, and generally limits the use of radar to sites overlain by less than $20 \mathrm{ft}$ of water (Gorin and Haeni, 1989).

For this study, an SIR 8 ground-penetrating radar unit manufactured by Geophysical Survey Systems Incorporated was used. In one configuration, two $100-\mathrm{mHz}$ antennas were used, one as a high-powered transmitter and the other as a receiver. In another configuration, a single $300-\mathrm{mHz}$ antenna was used as a transmitter and receiver.

\section{Continuous Seismic Reflection Using a Color Fathometer}

The color fathometer used in this study was a model HE-730, manufactured by Si-Tex Incorporated. This fathometer operates with a 4-inch transducer that transmits and receives acoustic pulses. The signal is digitized and displays a color image on a cathode-ray tube. Because the color displayed depends on the amplitude of the reflected signal, different colors can be associated with different physical properties of the bottom or subbottom materials. Thus, qualitative information can be obtained. Penetration of the subbottom surface may be limited because the color fathometer operates at a frequency between 20 and $100 \mathrm{kHz}$. Data output from the color fathometer is stored on digital audio tape. By processing the tape with computer software, hard copies of the record can be obtained.

\section{Continuous Seismic Reflection Using a Tuned Transducer}

Acoustic sources available for use in seismic reflection surveys are airguns, sparkers, unibooms, and a tuned transducer. Each source has its own penetration, frequency, and resolution characteristics (fig. 6). The tuned transducer was used for this study primarily because of its ease of use and because the penetration and resolution characteristics were acceptable for this study. The transducer operated at a frequency of $3.5 \mathrm{kHz}$ or at a frequency of $7.0 \mathrm{kHz}$. The instrumentation and transducer were manufactured by Ferranti O.R.E. Incorporated.

The tuned transducer system consisted of the transducer, transmitter, receiver, graphic recorder, and tape recorder. The transmitter controls pulse length and provides the electrical power at the proper frequency for driving the transducer. The receiver amplifies the electrical signals coming from the transducer for display on the graphic recorder. Data were recorded on an audio digital tape for playback.

In analyzing the output records from the ground-penetrating radar, the color fathometer, and the tuned transducer, multiples were often recorded and are noted. Multiples occur when the acoustic signal reflected from the streambed is reflected again at the air/water interface. If enough energy remains in this re-reflected signal, it can travel a number of times between the air/water interface and the streambed. Each multiple reflection from the bottom will produce an output on the seismic record until the signal level is too low to be detected. 
SOURCE FREQUENCY RANGE, IN KILOHERTZ

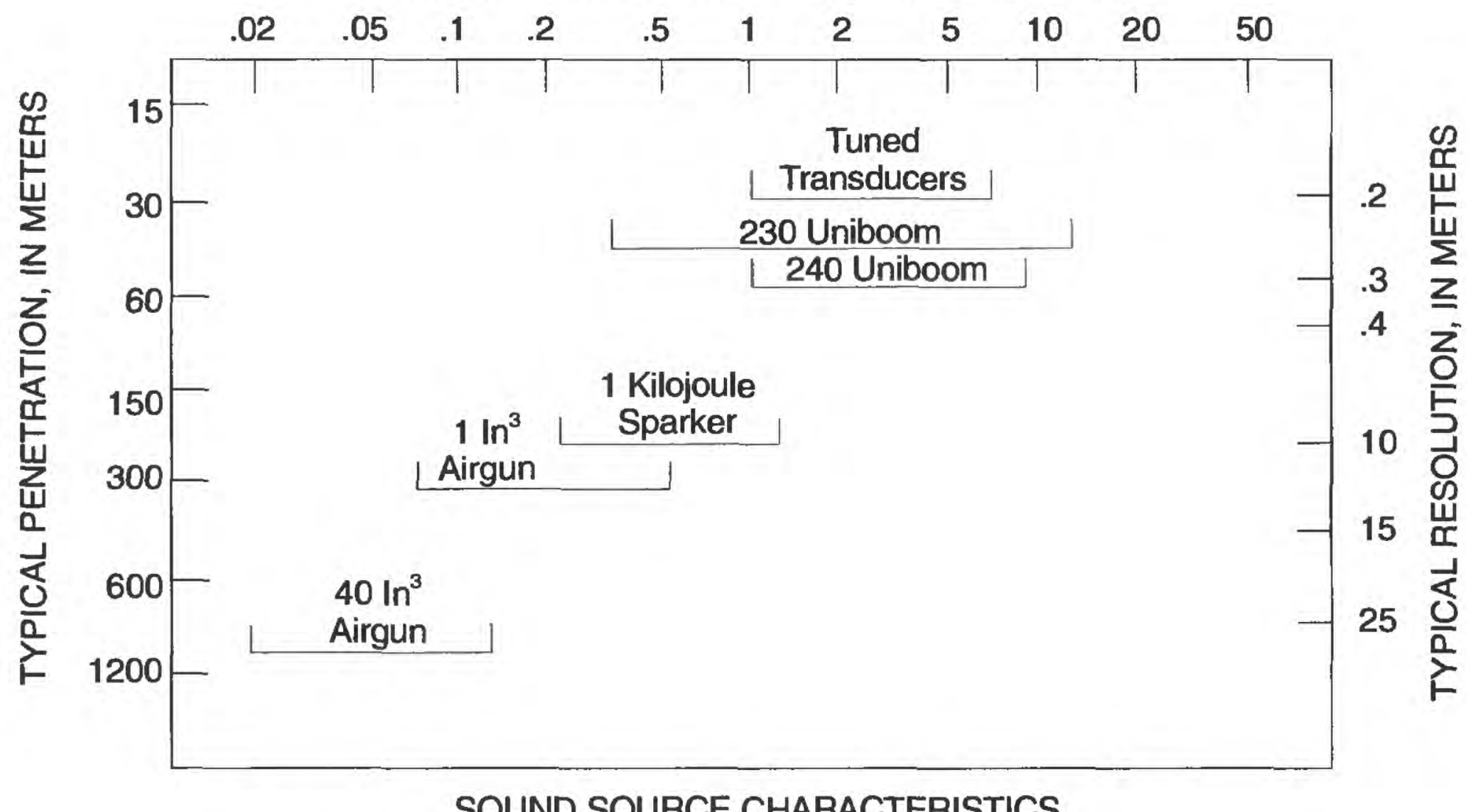

Figure 6. Characteristics of seismic reflection sound sources [modified from Sylwester, 1983].

\section{APPLICATION OF SURFACE GEOPHYSICAL TECHNIQUES}

\section{Bridges 331, 1187, and 332}

Bridges 331, 1187, and 332 (fig. 3) are located at Flag Point, Mile 27 of the Copper River Highway. Traveling east from Cordova, these are the first bridges that cross the Copper River. The bridges were constructed during 1970-72 to replace bridges damaged by the 1964 earthquake. Each bridge is supported by concrete piers that are $5.5 \mathrm{ft}$ wide, $18 \mathrm{ft}$ long, and pointed at both upstream and downstream ends. Bridges 331 and 332 are both $780 \mathrm{ft}$ long and supported by three piers spaced $220 \mathrm{ft}$ apart. Bridge 1187 is $1,220 \mathrm{ft}$ long and is supported by five piers spaced $220 \mathrm{ft}$ apart. Spur dikes were constructed at the left upstream abutment of Bridge 331 and at both upstream abutments of Bridge 1187 (figs. 7-9) (Note: figures 7 to 33 are at the end of the report, starting on p. 17.)

Data collected during the open-water periods of 1991 and 1992 (Brabets, 1992; 1993) are summarized in table 1. For this part of the study area, most of the flow is through Bridge 331 . On the basis of the percentage of suspended sediment that is finer than $0.062 \mathrm{~mm}$, most of the suspended sediment is classified as silt or clay. The median diameter of bedload, which ranges from 0.4 to $3.0 \mathrm{~mm}$, is characterized as medium sand to very fine gravel. Borings at these three bridges and the corresponding geologic cross sections indicate that the riverbed is composed primarily of gravelly sand and sandy gravel at Bridge 331 (fig. 10). At Bridge 1187 (fig. 11) and Bridge 332 (fig. 12), the riverbed is composed of loose to firm fine sand with fine gravel and silt. 
Table 1. Data from Bridges 331, 1187, and 332 on the Copper River Highway during open-water periods, 1991-92

[mg/L, milligrams per liter; mm, millimeter]

\begin{tabular}{|c|c|c|c|c|c|}
\hline \multirow[b]{2}{*}{ Bridge } & \multirow{2}{*}{$\begin{array}{l}\text { Water discharge } \\
\text { range } \\
\text { (cubic feet per } \\
\text { second) }\end{array}$} & \multicolumn{2}{|c|}{ Suspended-sediment } & \multicolumn{2}{|c|}{ Bedload } \\
\hline & & $\begin{array}{c}\text { Range in } \\
\text { concentration } \\
(\mathrm{mg} / \mathrm{L})\end{array}$ & $\begin{array}{c}\text { Range in } \\
\text { percent finer } \\
\text { than } 0.062 \mathrm{~mm}\end{array}$ & $\begin{array}{c}\text { Range in } \\
\text { discharge } \\
\text { (tons per day) }\end{array}$ & $\begin{array}{c}\text { Range in median } \\
\text { diameter }\left(\mathrm{D}_{50}\right) \\
(\mathrm{mm})\end{array}$ \\
\hline 331 & $16,600-56,600$ & $503-2,298$ & $77-98$ & $550-4,300$ & $0.4-3.0$ \\
\hline 1187 & $0-38,600$ & $309-2,156$ & $78-98$ & $1,300-4,690$ & $.4-1.8$ \\
\hline 332 & $0-29,400$ & $560-2,095$ & $74-98$ & $400-3,800$ & $.5-.9$ \\
\hline
\end{tabular}

Ground-penetrating radar was used at Bridges 331 and 1187 in August 1991, and continuous seismic reflection using the tuned transducer was used at all three sites in June 1992. Both methods were used for several reasons: (1) to familiarize and train personnel in the use of the equipment, (2) to ascertain if the ground-penetrating radar would work in depths greater than $20 \mathrm{ft}$, and (3) to ascertain which method would provide sufficient penetration, given the type of material of the riverbed.

At Bridge 331, a comparison of cross sections obtained from the downstream side of the bridge indicates that two main channels have formed at this bridge since 1968 (fig. 13). Because the cross section data also indicated that scour has taken place at all three piers, the geophysical methods were tested at all three piers.

Using the $100-\mathrm{mHz}$ antennas, the ground-penetrating radar provided a good record of an infilled scour hole near pier 3 (fig. 14). This profile was taken approximately $15 \mathrm{ft}$ upstream from pier 3, moving from the right edge to the left edge of water and is approximately $70 \mathrm{ft}$ wide. Using a value of $0.11 \mathrm{ft} / \mathrm{ns}$ for radar waves in fresh water and a value of $0.20 \mathrm{ft} / \mathrm{ns}$ for radar waves in saturated sediments, the depth of this scour hole was about $12 \mathrm{ft}$ (fig. 14). The profile did not show any infilled scour holes near piers 1 and 2.

Continuous seismic reflection using a $7.0-\mathrm{kHz}$ tuned transducer also provided good data at Bridge 331. A profile was taken $50 \mathrm{ft}$ upstream from pier 1, moving from right edge to the left edge of the water. This profile indicated two infilled scour holes (fig. 15); one scour hole approximately $5 \mathrm{ft}$ deep was filled with boulders and the other scour hole approximately $15 \mathrm{ft}$ deep was filled with fine-grained sediments.

No infilled scour holes were detected at pier 2 either by ground-penetrating radar or by continuous seismic reflection. Because debris from the original bridge was still near the pier, the airboat was not able to navigate closer than about $100 \mathrm{ft}$ from the upstream end of the pier. Closer to the pier, scour holes may be present.

Inspection of cross sections taken from the downstream side of Bridge 1187 (fig. 16) indicates that scour and infill have occurred primarily near piers 3 and 4 . Using these data as a guide, efforts were focused on inspecting piers 3 and 4, using ground-penetrating radar and continuous seismic reflection with the tuned transducer. 
Using the $300-\mathrm{mHz}$ antennas, a ground-penetrating radar profile was taken approximately $50 \mathrm{ft}$ upstream from Bridge 1187, moving from the right bank to the left bank. The section shown in figure 17 is approximately $150 \mathrm{ft}$ wide near pier 3 . At the deepest section, no infilled scour hole is apparent, most likely because the depth-approximately $24 \mathrm{ft}$-is outside the range of the ground-penetrating radar. Moving towards the left bank, there appears to be some infill.

Continuous seismic reflection using a 7.0-kHz-tuned transducer at approximately the same location provided more information (fig. 18). This technique was able to penetrate the subbottom to a greater degree than the ground-penetrating radar. About $3 \mathrm{ft}$ of infill apparently occurs at the deepest part of the section, and some infill seems to appear towards pier 4.

Comparison of cross sections of the Copper River obtained from the downstream side of Bridge 332 (fig. 19) indicates that the channel at this location is unstable. For example, it appears that the channel has filled in between 1968 and June 1992. However, between June 9, 1992 and September 18, 1992, a significant quantity of scour occurred between piers 1 and 2. Thus, the approach taken at this site was to examine all three piers.

Using continuous seismic reflection with a $7.0-\mathrm{kHz}$ tuned transducer, a profile was obtained approximately $50 \mathrm{ft}$ upstream from the bridge, traversing from the left bank to the right bank. This profile (fig. 20) showed about $3 \mathrm{ft}$ of infill near pier 2, some debris between piers 2 and 3 , and some infill near pier 3.

Longitudinal profiles were obtained along each pier. At piers 2 and 3, no significant infill was noted. Along pier 1, using the $7.0-\mathrm{kHz}$ tuned transducer, about $3 \mathrm{ft}$ of infill was noted toward the upstream part of the pier (fig. 21). A side echo from either the pier or the pier footing was also detected.

\section{Bridge 334}

Bridge 334 is located at Mile 34.9 of the Copper River Highway and was constructed during 1976-78. The bridge is $1,200 \mathrm{ft}$ long and is supported by 14 sets of concrete-filled steel cylindrical pipe spaced $80 \mathrm{ft}$ apart (fig. 22). Each pipe is circular and has a diameter of $30 \mathrm{in}$., and the two pipes in a set are connected by a concrete cap. Spur dikes were constructed at the upstream abutments and the design discharge for the bridge is $82,000 \mathrm{ft}^{3} / \mathrm{s}$.

At one time, a significant portion of the Copper River flowed under Bridge 334. Over time, the channels of the Copper River have shifted, and most of the flow presently is distributed among Bridges $331,1187,332$, and 342 . In 1968, before construction of the present bridge, the main channel was approximately 850 to $950 \mathrm{ft}$ from the left abutment (fig. 23). However, since construction of Bridge 334, this part of the channel had filled in, and in 1992 the main channel was approximately 1,050 to $1,150 \mathrm{ft}$ from the left abutment.

Although only an insignificant quantity of flow now passes through Bridge 334, groundpenetrating radar was tested at this site. The purpose was to determine if this geophysical method could detect the old river channel. Ground-penetrating radar was the only technique used because the seismic reflection techniques could not be used on dry land.

Using the $100-\mathrm{mHz}$ antennas, a ground-penetrating radar profile was obtained at the upstream side of the bridge (fig. 24). The profile showed a water depth of about $27 \mathrm{ft}$. Moving towards the left abutment, the ground-penetrating radar indicated an area of infill which is probably the old channel. The depth of infill was estimated to be approximately $30 \mathrm{ft}$ and probably consisted of finegrained sediments. Thus, it appears that this geophysical method is useful in detecting old river channels. 


\section{Bridge 342}

Bridge 342 is located at Mile 37.3 of the Copper River Highway. When this bridge was constructed in 1976-78, the original railroad bridge it replaced was $282 \mathrm{ft}$ long. The replacement bridge, when constructed, was $400 \mathrm{ft}$ long and supported by four sets of steel piers spaced $80 \mathrm{ft}$ apart.

Significant channel changes have occurred at Bridge 342. Parts of the main channel of the Copper River have shifted, probably during the relatively high floods of the 1970's and the early 1980 's. As a result of the channel shifting, severe scour occurred at Bridge 342, resulting in major repairs in 1987. These repairs consisted of extending the bridge $240 \mathrm{ft}$ on each side and constructing spur dikes at the left and right upstream abutments (fig. 25). The spur dikes were subsequently overtopped and destroyed during a high-water period in 1989 and rebuilt in 1991. Presently, about 40 percent of the discharge of the Copper River flows under Bridge 342.

During the open-water periods of 1991 and 1992, discharge at Bridge 342 ranged from 13,400 to $91,400 \mathrm{ft}^{3} / \mathrm{s}$ (Brabets, 1992; 1993). These discharges represent between 33 and 67 percent of the total flow of the Copper River past the Million Dollar Bridge. Suspended-sediment concentrations ranged from 262 to $2,316 \mathrm{mg} / \mathrm{L}$. Most of the sediment is finer than $0.062 \mathrm{~mm}$. Bedload discharge ranged from 1,000 to 14,700 ton/d. The range in bedload transport probably reflects the scouring of a gravel bar just upstream from the bridge. Median diameter, $\mathrm{d}_{50}$, of the bedload ranged from 0.8 to $16.0 \mathrm{~mm}$. The generalized geology in the vicinity of the bridge (fig. 26) indicates that the riverbed is composed of sandy gravel.

Ground-penetrating radar and continuous seismic reflection using a color fathometer were used at Bridge 342 in August 1991. Continuous seismic reflection using a tuned transducer was used in June 1992. Profiles were obtained with all three methods at locations east of the spur dike, upstream and downstream from the bridge, and laterally near piers 9 and 10 (fig. 25).

The color fathometer provided good records of the depth to the river bottom and was useful in determining the depth of an existing scour hole located off the tip of the spur dike (fig. 27). The scour hole was approximately $60 \mathrm{ft}$ deep and $70 \mathrm{ft}$ wide. However, the color fathometer did not provide subbottom information. The ground-penetrating radar, using $300-\mathrm{mHz}$ antennas, also was not able to penetrate the subbottom in areas where the water depths were greater than $20 \mathrm{ft}$. One ground-penetrating radar profile, in water approximately $10 \mathrm{ft}$ deep, did show an infilled scour hole near pier 5 (fig. 28), about $10 \mathrm{ft}$ thick.

Because of the relatively deep water and fast currents at this site, no attempts were made to use the $7.0-\mathrm{kHz}$ transducer. Instead, continuous seismic reflection was done using a $3.5-\mathrm{kHz}$ transducer. Although the $3.5-\mathrm{kHz}$ transducer did not provide as much penetration of the subbottom as the $7.0-\mathrm{kHz}$ transducer did, it still proved to be the most useful technique at this site. A profile upstream from the bridge (fig. 29) indicated slight infill in some areas, but no significant infilled holes were detected. The reasons may be that the material is relatively similar, the channel is undergoing constant scouring and infilling, and no residual infill material was present at the time of this study.

\section{Miles Lake}

Miles Lake (fig. 1) is a proglacial lake formed by the retreat of Miles Glacier. As the Copper River enters Miles Lake from the north, it transports approximately 65 million tons of suspended sediment annually into the lake (Emery and others, 1985). Most of the suspended sediment is trans- 
ported during the open-water season (May through September). Comparison of sketch maps made from aerial photographs of Miles Lake (fig. 30) shows that from 1950 to 1985, the northwestern part of the lake has gradually filled in and that the southern terminus of Miles Glacier has retreated. Today, the Copper River flows southward along the face of Miles Glacier, and then turns westward towards the Million Dollar Bridge.

On the basis of borings collected near the Million Dollar Bridge in 1980 (fig. 31), it was determined that the bottom of Miles Lake probably consists of large boulders, cobbles, and gravel. Also, data collected at the Million Dollar Bridge in 1991 and 1992 indicated that no bedload was being transported past the Million Dollar Bridge (Brabets, 1992; 1993). To determine whether Miles Lake might be a sediment trap for bedload being transported by the Copper River north of Miles Lake, continuous seismic reflection methods were used in June 1992 to determine the depositional features of the bottom sediments in Miles Lake.

Four north/south and one east/west continuous seismic reflection profiles of Miles Lake were obtained using a 7-kHz tuned transducer. North/south profile 1 (fig. 32), which was the closest to the face of Miles Glacier, provided considerable information. The hyperbolic reflections (refer to figure 4) were probably due to the presence of large boulders on the riverbed. This part of the lake is generally considered an ice marginal or ice proximal fan which consists of very coarse material and is formed from debris washing out from tunnels at the base of the glacier. In addition, the depth of water in this profile was relatively deep.

Profile 2 (fig. 33) was also a north/south profile taken approximately 1 mi downstream from Miles Glacier. This profile also provided considerable information. In this section, the depth of water was fairly uniform and a distinct layer of fine-grained sediments was present. This layer ranged in thickness from about $2 \mathrm{ft}$ to about $8 \mathrm{ft}$ and overlies a coarser grain deposit which is most likely the glacier deposited material.

The remaining downstream profiles of Miles Lake showed similar characteristics of the finegrained sediments overlying the glacially deposited material. These results, as well as the results of the bedload sampling at the Million Dollar Bridge, indicate that most, if not all, of the bedload transported by the Copper River is deposited once it enters Miles Lake.

\section{SUMMARY AND CONCLUSIONS}

Three surface geophysical methods-ground-penetrating radar, continuous seismic reflection using a color fathometer, and continuous seismic reflection using a tuned transducer-were tested in a study of the geomorphology of the lower Copper River. Principal findings are:

- Ground-penetrating radar proved effective on dry land in detecting an old river channel. If the depth of water was less than about $20 \mathrm{ft}$, the radar was also effective in detecting infilled scour holes at bridge piers.

- Continuous seismic reflection using the color fathometer was tested at one location. This technique was useful in determining the depth of water, but it did not provide sufficient penetration of the subbottom.

- Continuous seismic reflection using a tuned transducer was effective in water. This method was able to detect infilled scour holes at bridge piers and deposits in a glacial lake. 
- Ground-penetrating radar using $100-\mathrm{mHz}$ antennas detected a 12 -foot scour hole near pier 3 at Bridge 331 on the Copper River Highway. Continuous seismic reflection using a 7-kHz tuned transducer detected two infilled holes near pier 1: one approximately $5 \mathrm{ft}$ deep consisting of boulders and one approximately $15 \mathrm{ft}$ deep filled with fine-grained sediments.

- At Bridge 1187, depths of water in some areas were greater than $20 \mathrm{ft}$ and results of using groundpenetrating radar were inconclusive. Continuous seismic reflection using a $7-\mathrm{kHz}$ transducer was effective in detecting an infilled scour hole, approximately $15 \mathrm{ft}$ deep, near pier 4 .

- Continuous seismic reflection using a 7-kHz transducer at Bridge 332 detected an infilled layer between piers 2 and 3, and an infilled scour hole adjacent to pier 1 .

- At Bridge 334, ground-penetrating radar using $100-\mathrm{mHz}$ antennas was used on dry land. This geophysical technique was able to detect the main river channel which existed at this site in 1968 and has since filled in.

- The three geophysical techniques were tested at Bridge 342. Continuous seismic reflection using a color fathometer detected a 60 -foot scour hole located off the tip of the left upstream spur dike but was not able to penetrate the subbottom. The ground-penetrating radar did detect an infilled scour hole near pier 5 . However, in the remainder of the area, depths were greater than $20 \mathrm{ft}$ and the ground-penetrating radar could not sufficiently penetrate the subbottom. Continuous seismic reflection with a $3.5-\mathrm{kHz}$ transducer did provide sufficient penetration but did not reveal any significant infilled holes, most likely because the channel at this site is undergoing constant change.

- Continuous seismic reflection using a 7-kHz tuned transducer was effective in detecting ice marginal fans near the terminus of Miles Glacier and a fine-grained sediment layer in the lake. These data, in conjunction with bedload data collected at the Million Dollar Bridge, indicate that Miles Lake traps virtually all the bedload that enters the lake from the Copper River.

\section{REFERENCES CITED}

Beres, Milan, Jr., and Haeni, F.P., 1991, Application of ground-penetrating-radar methods in hydrogeologic studies: Ground Water, v. 29, no. 3, p. 375-386.

Brabets, T.P., 1992, Hydrologic data for the lower Copper River, Alaska, May to September 1991: U.S. Geological Survey Open-File Report 92-89, 15 p.

1993, Hydrologic data for the lower Copper River, Alaska, May to September 1992: U.S. Geological Survey Open-File Report 93-162, 26 p.

1994, Scour assessment at bridges from Flag Point to Million Dollar Bridge, Copper River Highway, Alaska: U.S. Geological Survey Water-Resources Investigations Report 94-4073, 57 p.

Crumrine, M.D., 1991, Results of a reconnaissance bridge-scour study at selected sites in Oregon using surfacegeophysical methods, 1989: U.S. Geological Survey Water-Resources Investigations Report 90-4199, 44 p.

Davis, J.L., and Annan, A.P., 1989, Ground-penetrating radar for high-resolution mapping of soil and rock stratigraphy: Geophysical Prospecting, v. 37, p. 531-551.

Emery, P.A., Jones, S.H., and Glass, R.L., 1985, Water resources of the Copper River Basin, Alaska: U.S. Geological Survey Hydrologic Investigations Atlas HA-686, 3 sheets.

Gorin, S.R., and Haeni, F.P., 1989, Use of surface-geophysical methods to assess riverbed scour at bridge piers: U.S. Geological Survey Water-Resources Investigations Report 88-4212, 33 p.

Haeni, F.P., 1986, Application of continuous seismic reflection methods to hydrologic studies: Ground Water, v. 24, no. 1, p. 23-31. 
1988a, Application of seismic-refraction techniques to hydrologic studies: U.S. Geological Survey Techniques of Water-Resources Investigations, book 2, chap. D2, 86 p.

$1988 \mathrm{~b}$, Evaluation of the continuous seismic-reflection method for determining the thickness and lithology of stratified-drift in the glaciated northeast, in Randall, A.D. and Johnson, I.A., eds., Regional aquifer systems of the United States-The northeast glacial aquifers: American Water Resources Association Monograph Series II, p. 1-20.

Olhoeft, G.R., 1984, Applications and limitations of ground-penetrating radar: Annual International Society for Exploration Geophysics Conference, 54th, Atlanta, Georgia, 1984, Proceedings, p. 147.

Sylwester, R.E., 1983, Single-channel, high-resolution seismic-reflection profiling-A review of the fundamentals and instrumentation, in Geyer, R.A., ed., Handbook of geophysical exploration at sea: Boca Raton, Florida, CRC Press, p. 77-122.

Wright, D.L., Olhoeft, G.R., and Watts, R.D., 1984, Ground-penetrating radar studies on Cape Cod: National Water Well Association-Environmental Protection Agency Conference on Surface and Borehole Geophysical Methods in Ground Water Investigations, San Antonio, Texas, 1984, Proceedings, p. 666-680. 


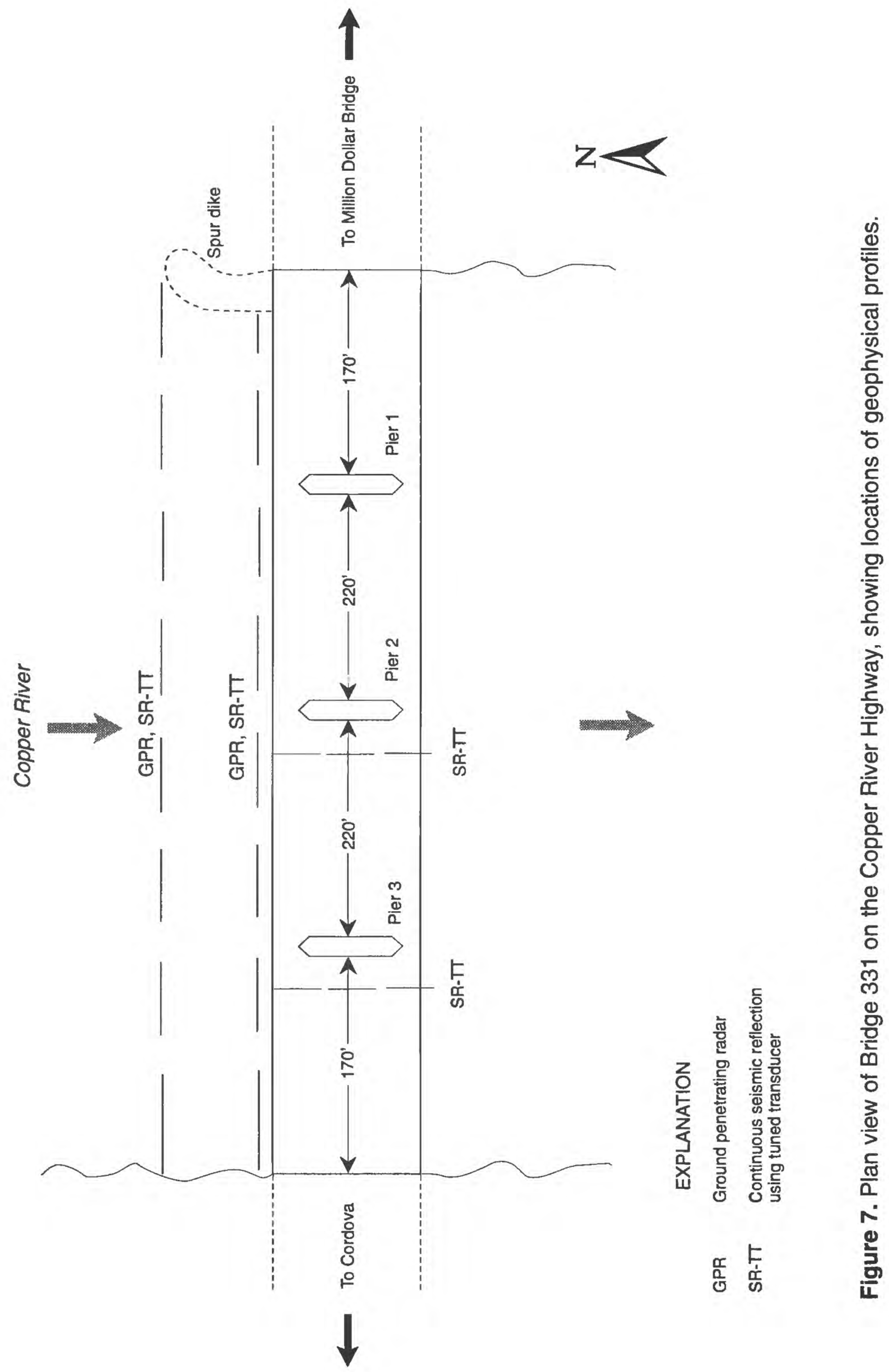



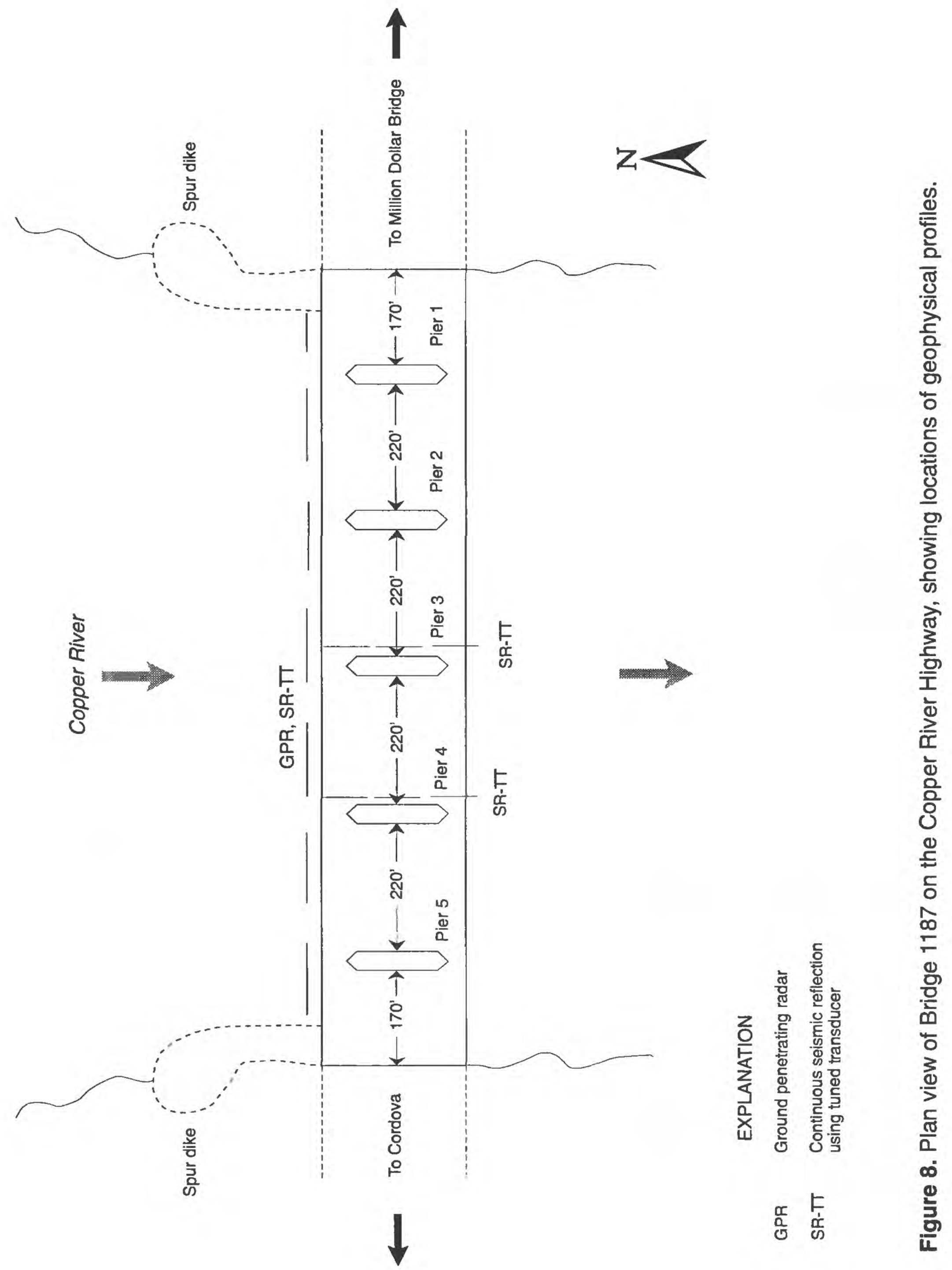


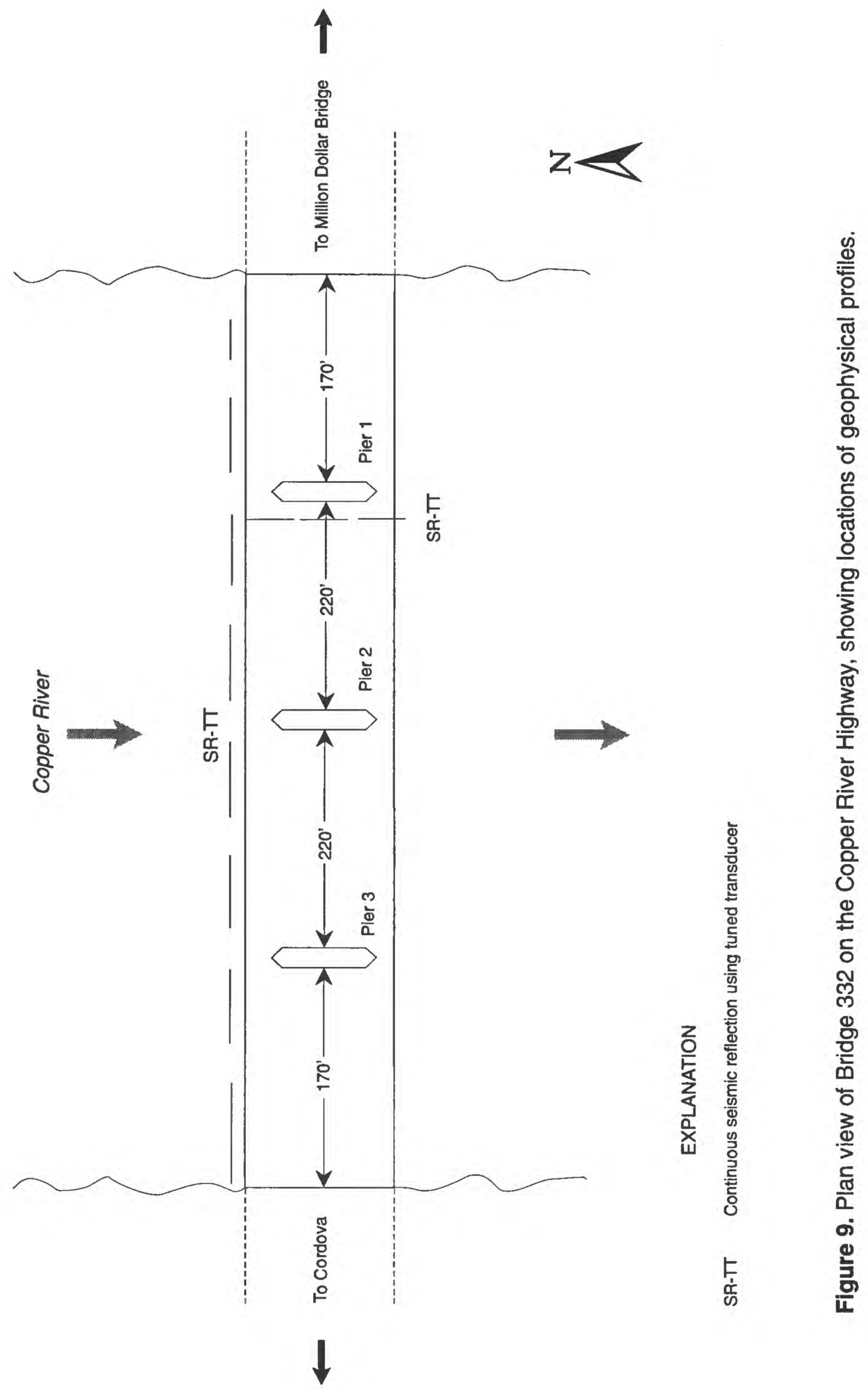




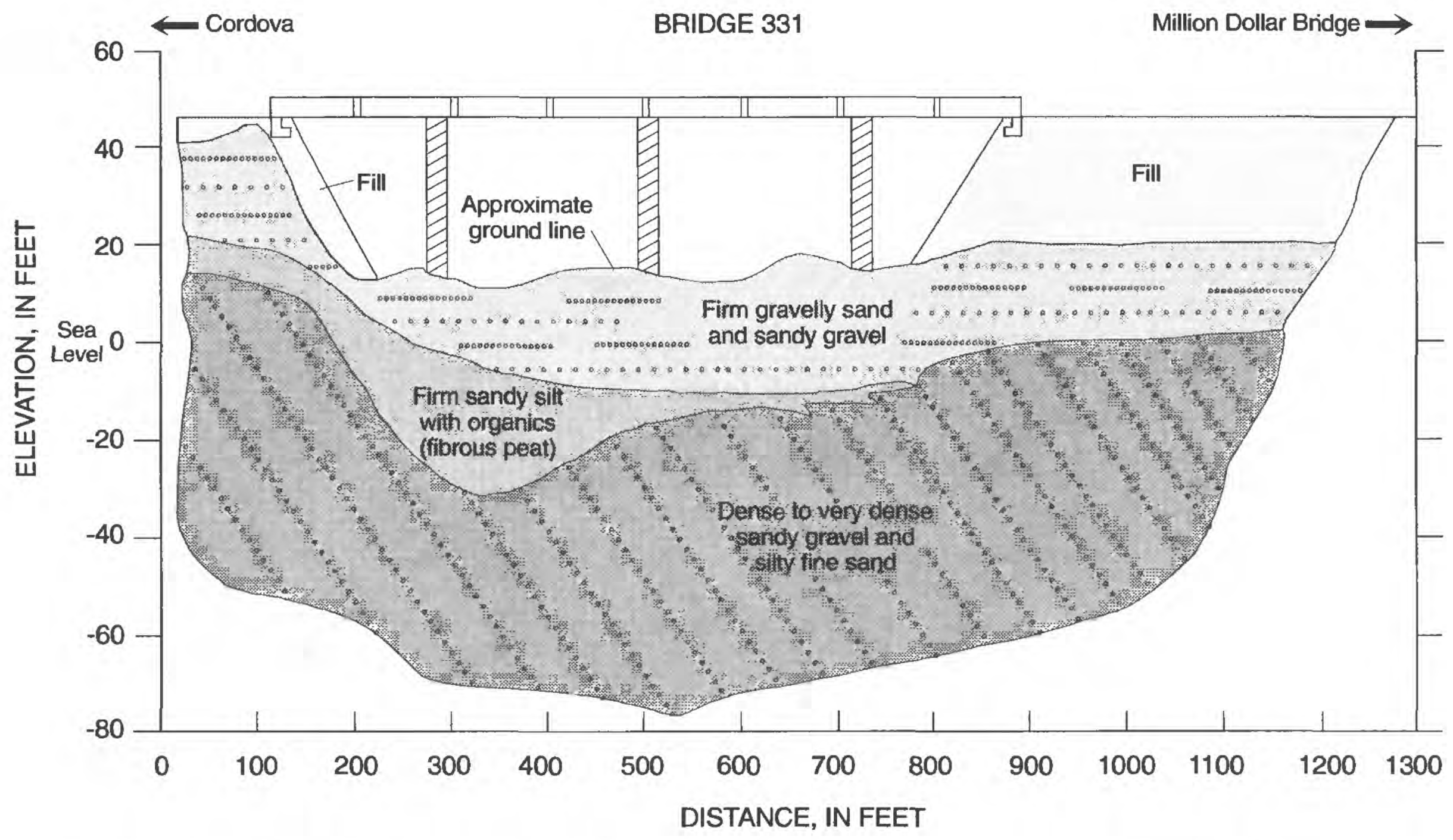

Figure 10. Generalized geologic cross section at Bridge 331 on the Copper River Highway, (modified from Alaska Department of Transportation and Public Facilities files). 


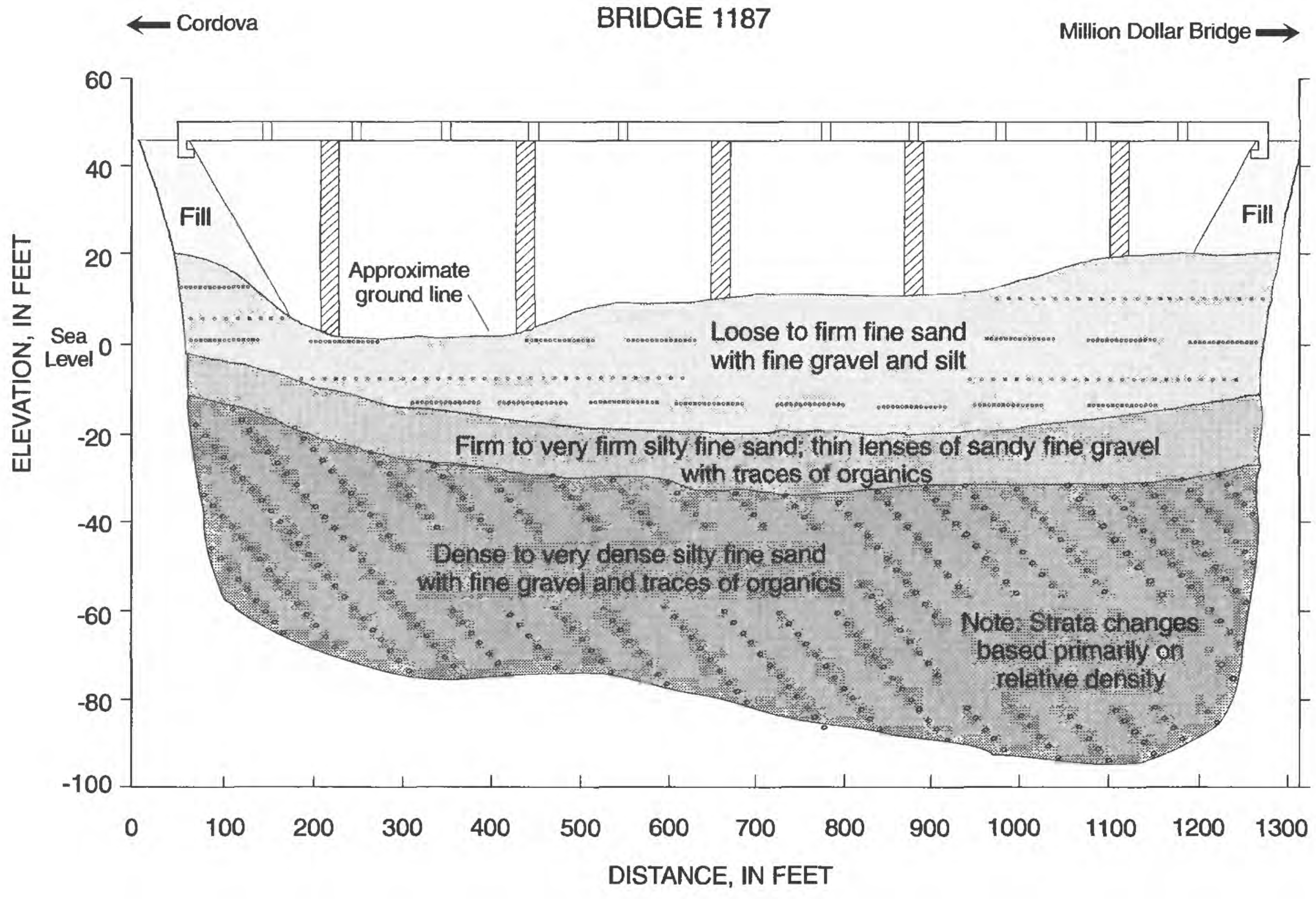

Figure 11. Generalized geologic cross section at Bridge 1187 on the Copper River Highway, (modified from Alaska Department of Transportation and Public Facilities files). 


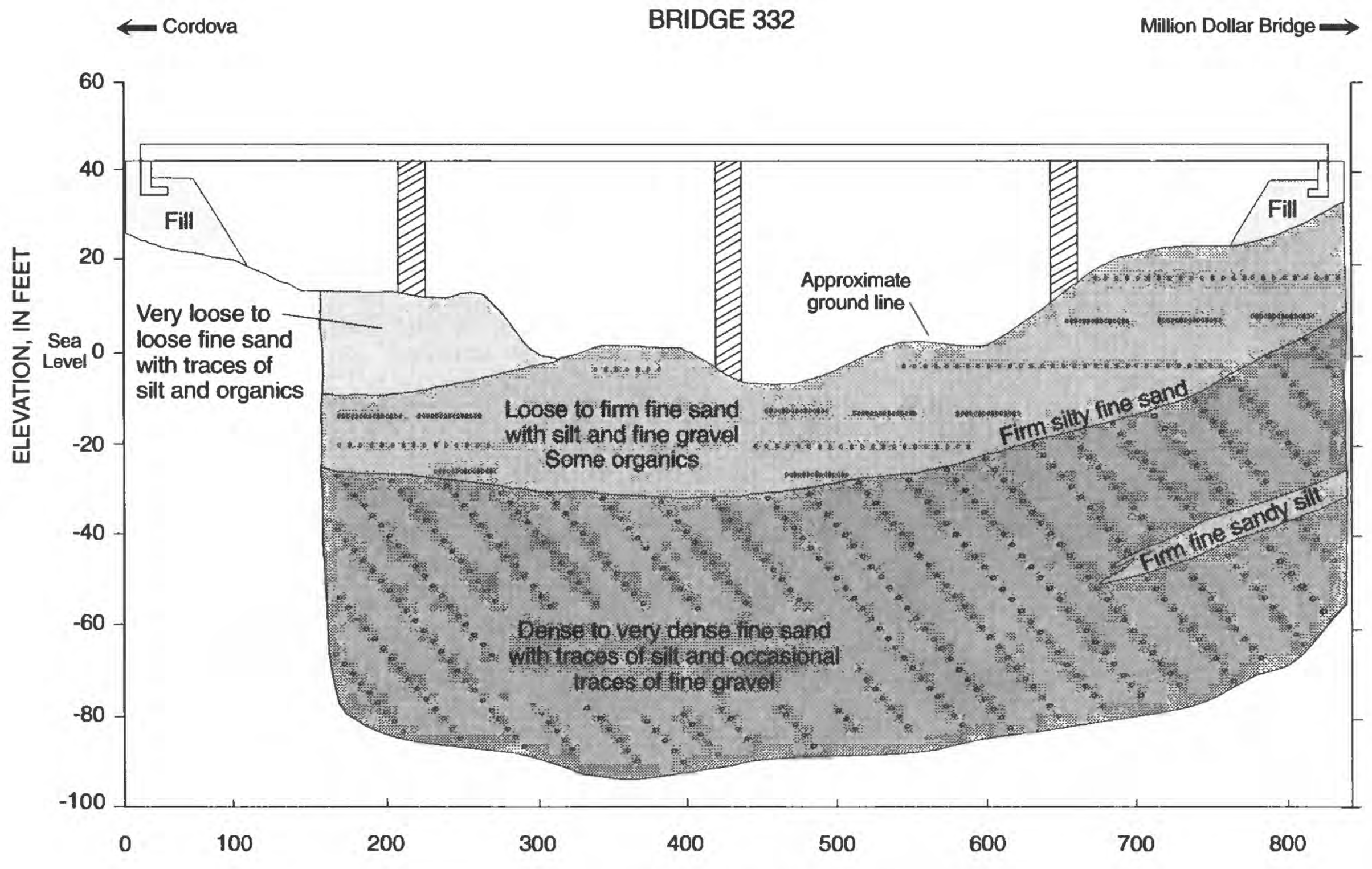

DISTANCE, IN FEET

Figure 12. Generalized geologic cross section at Bridge 332 on the Copper River Highway, (modified from Alaska Department of Transportation and Public Facilities files). 


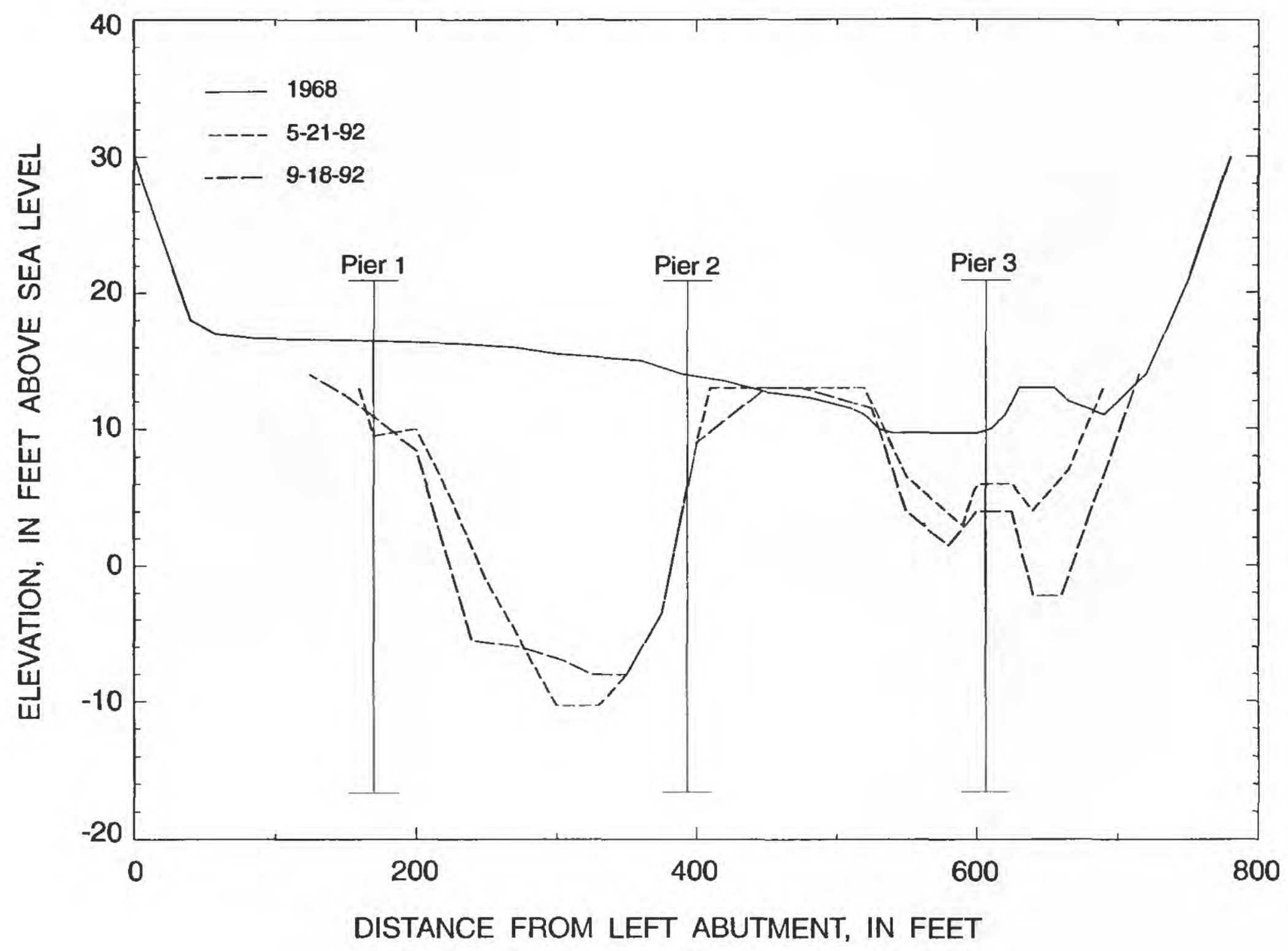

Figure 13. Cross sections of the Copper River, downstream side of Bridge 331. 

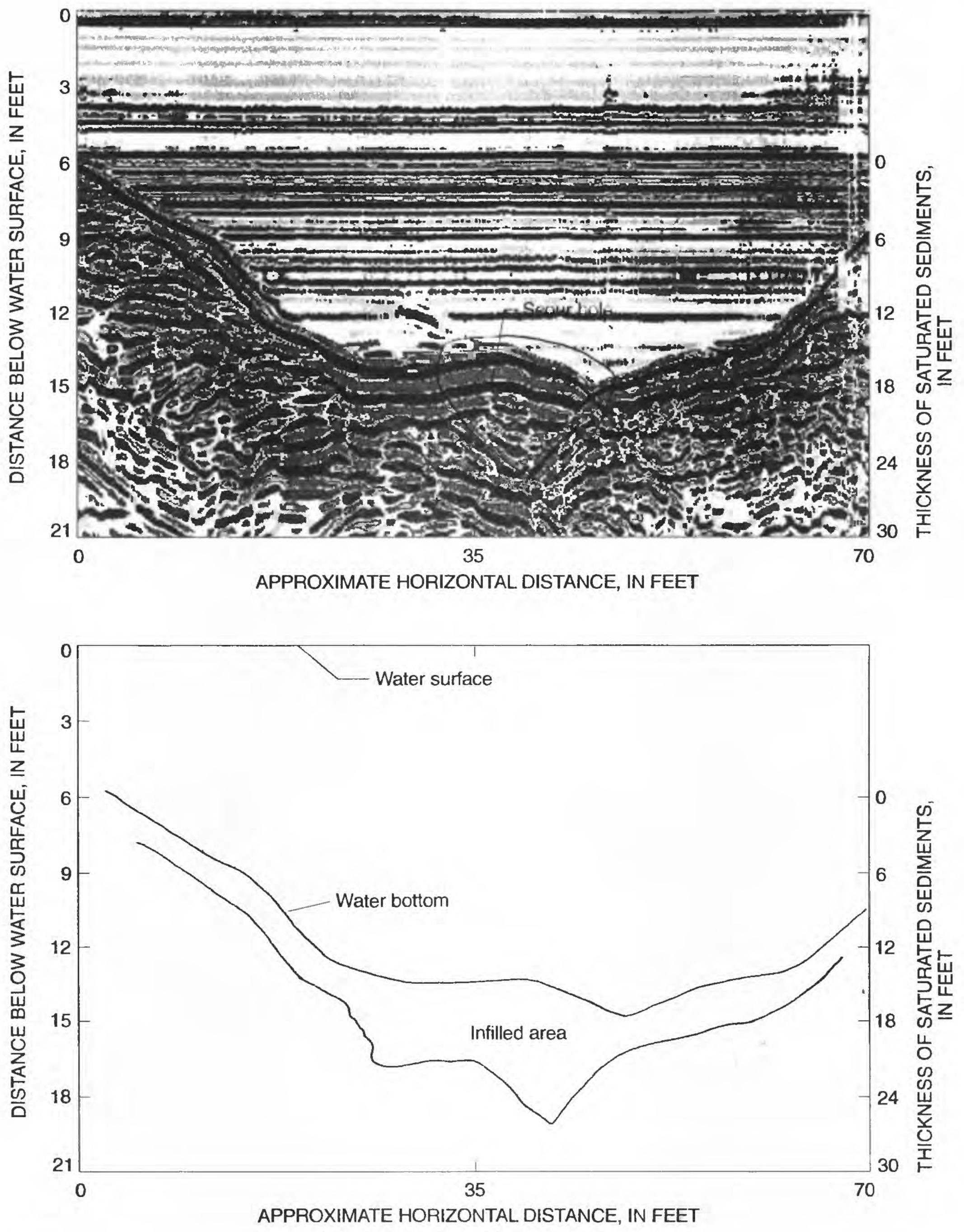

Figure 14. Record of a 100-mHz ground-penetrating radar cross section and interpretation of infilled area at Bridge 331 near pier 3, on the Copper River Highway. 


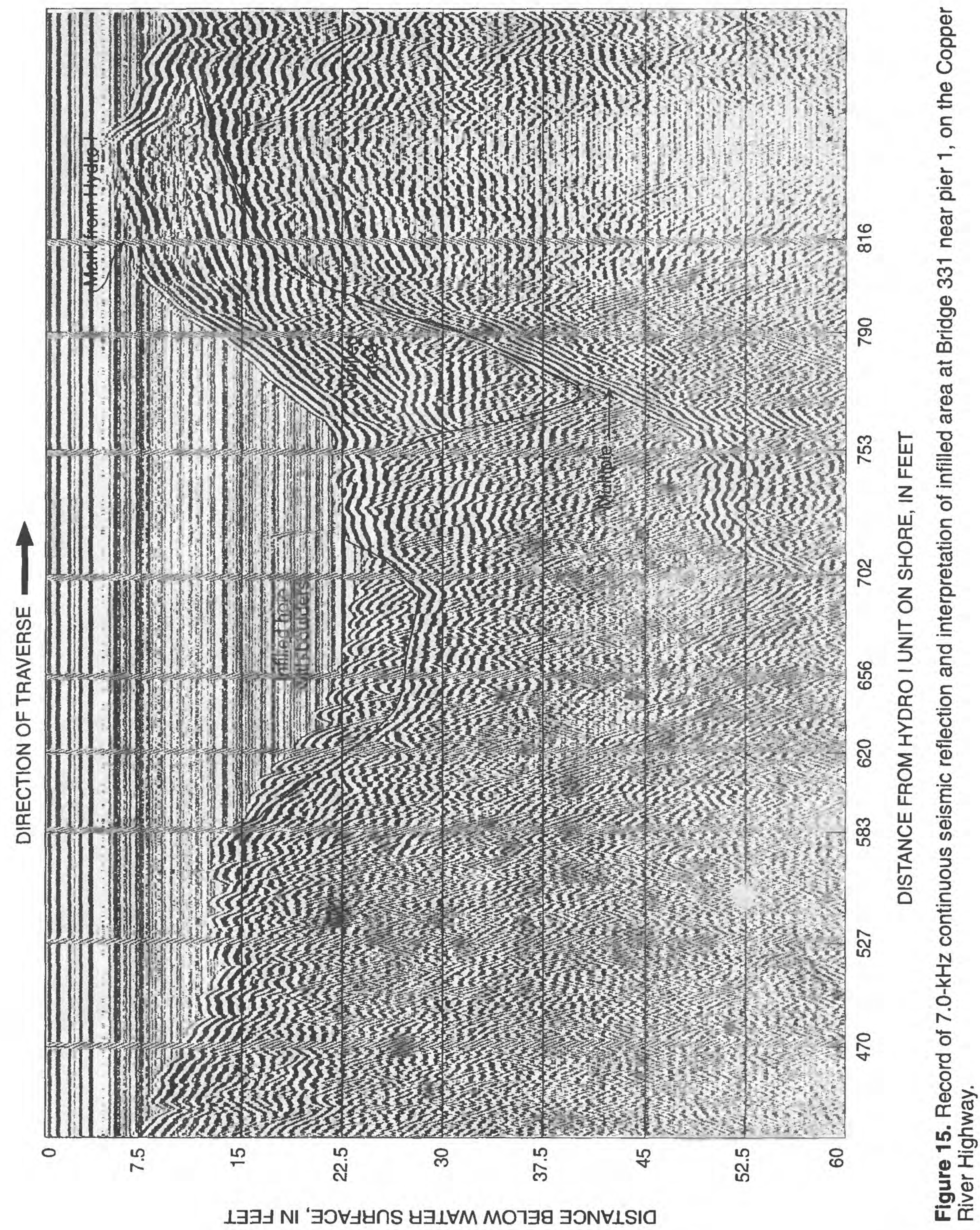




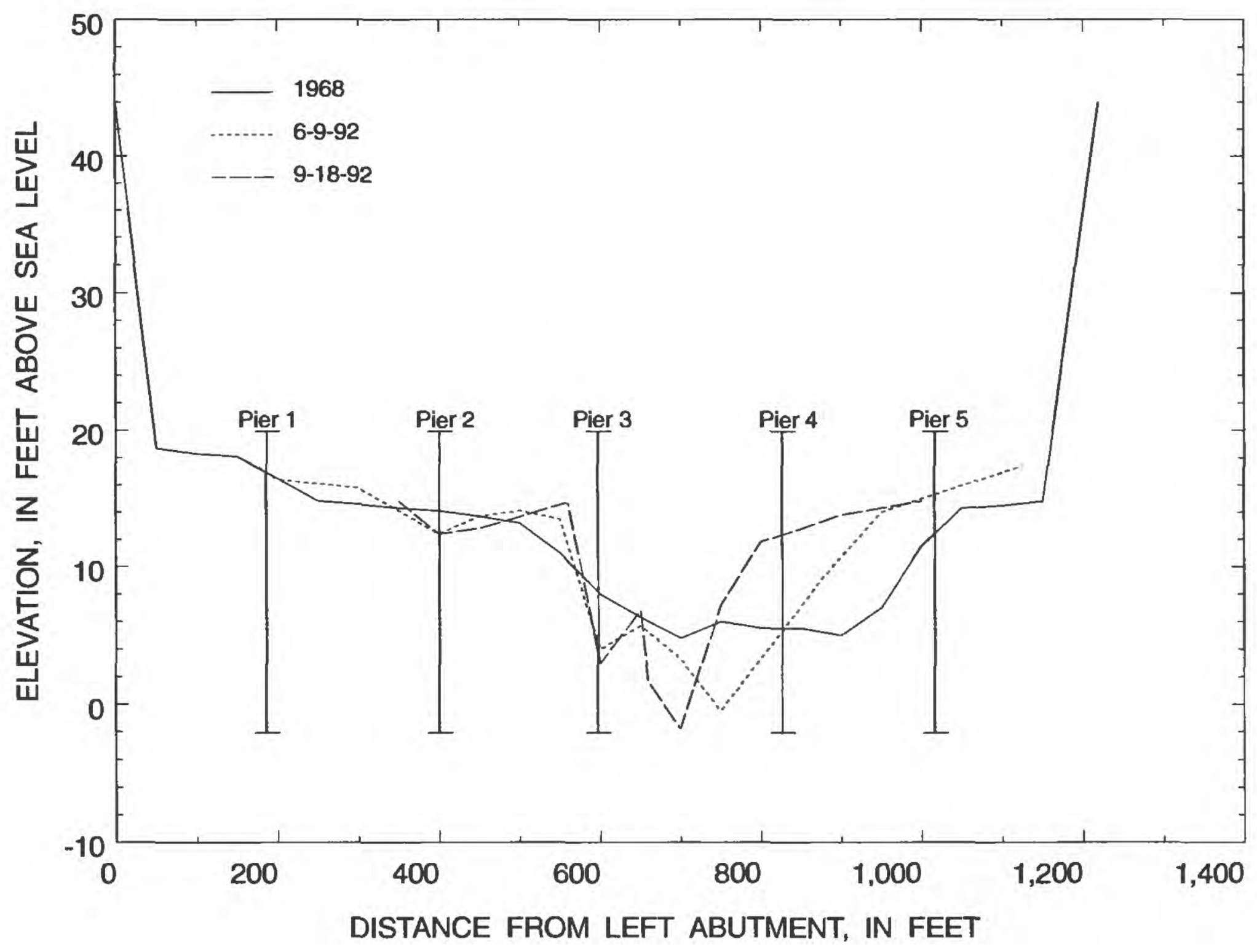

Figure 16. Cross sections of the Copper River, downstream side of Bridge 1187. 


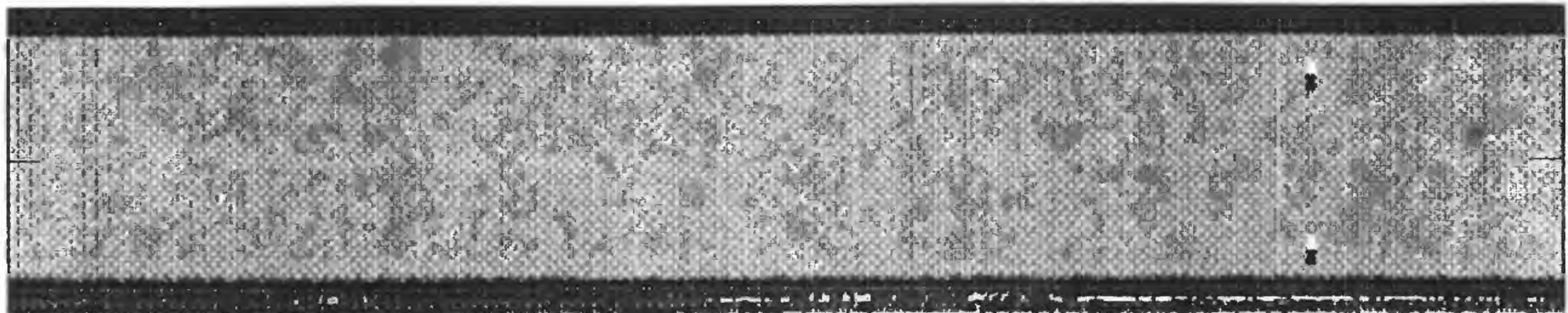

6

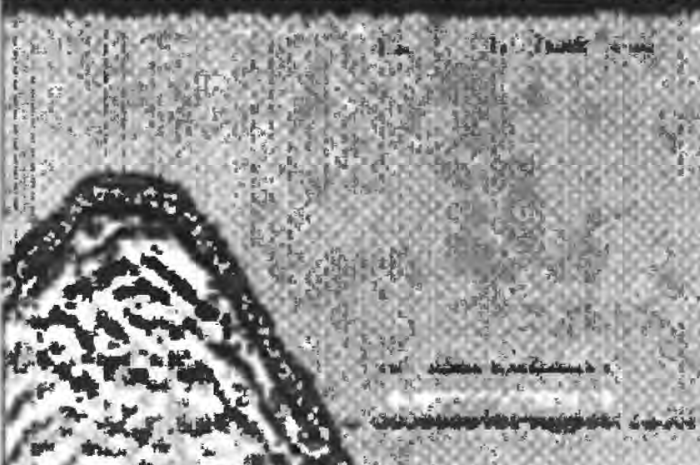

\section{arominat}

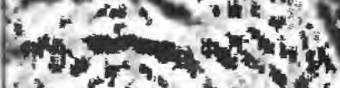

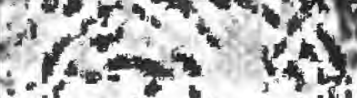

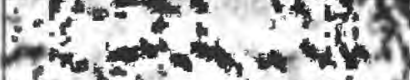

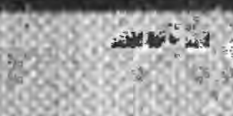

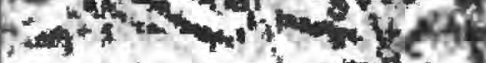

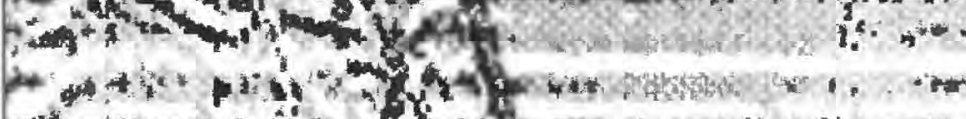

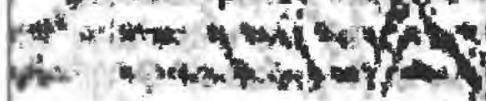

18

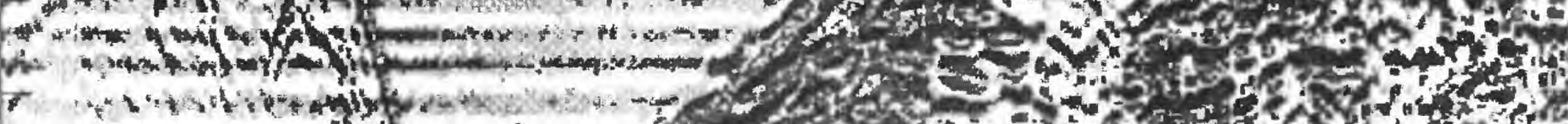
(3)

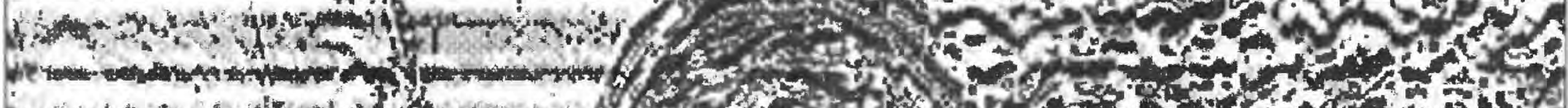

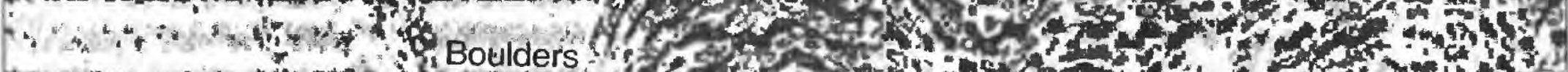

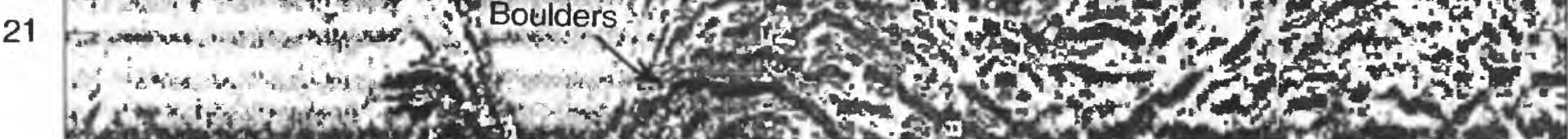

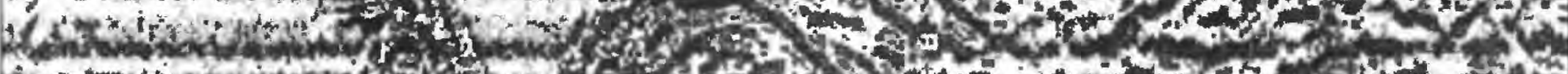

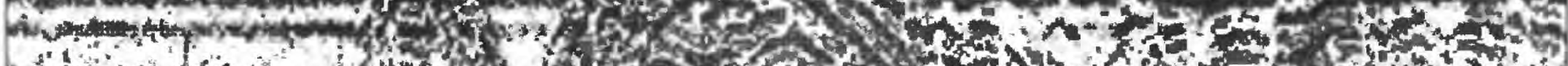

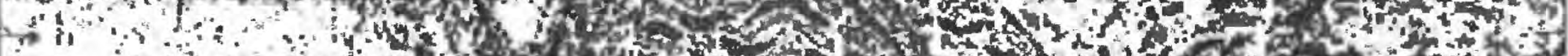

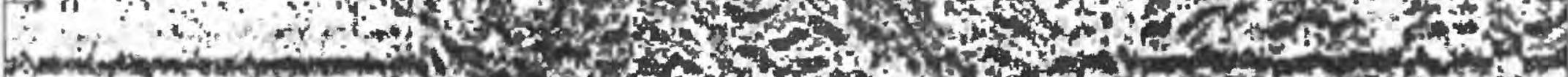
2. and

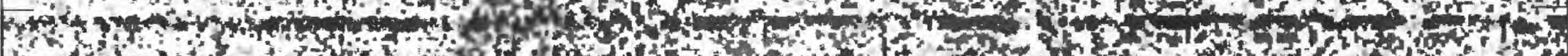
\% ind

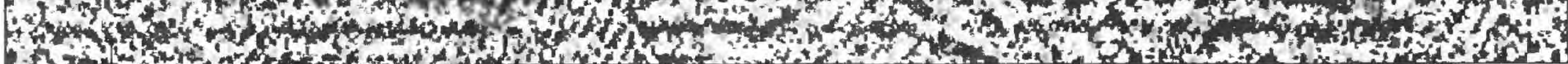
0 80

APPROXIMATE HORIZONTAL DISTANCE, IN FEET

Figure 17. Record of $300-\mathrm{mHz}$ ground-penetrating radar cross section from Bridge 1187 near pier 3, on the Copper River Highway. 


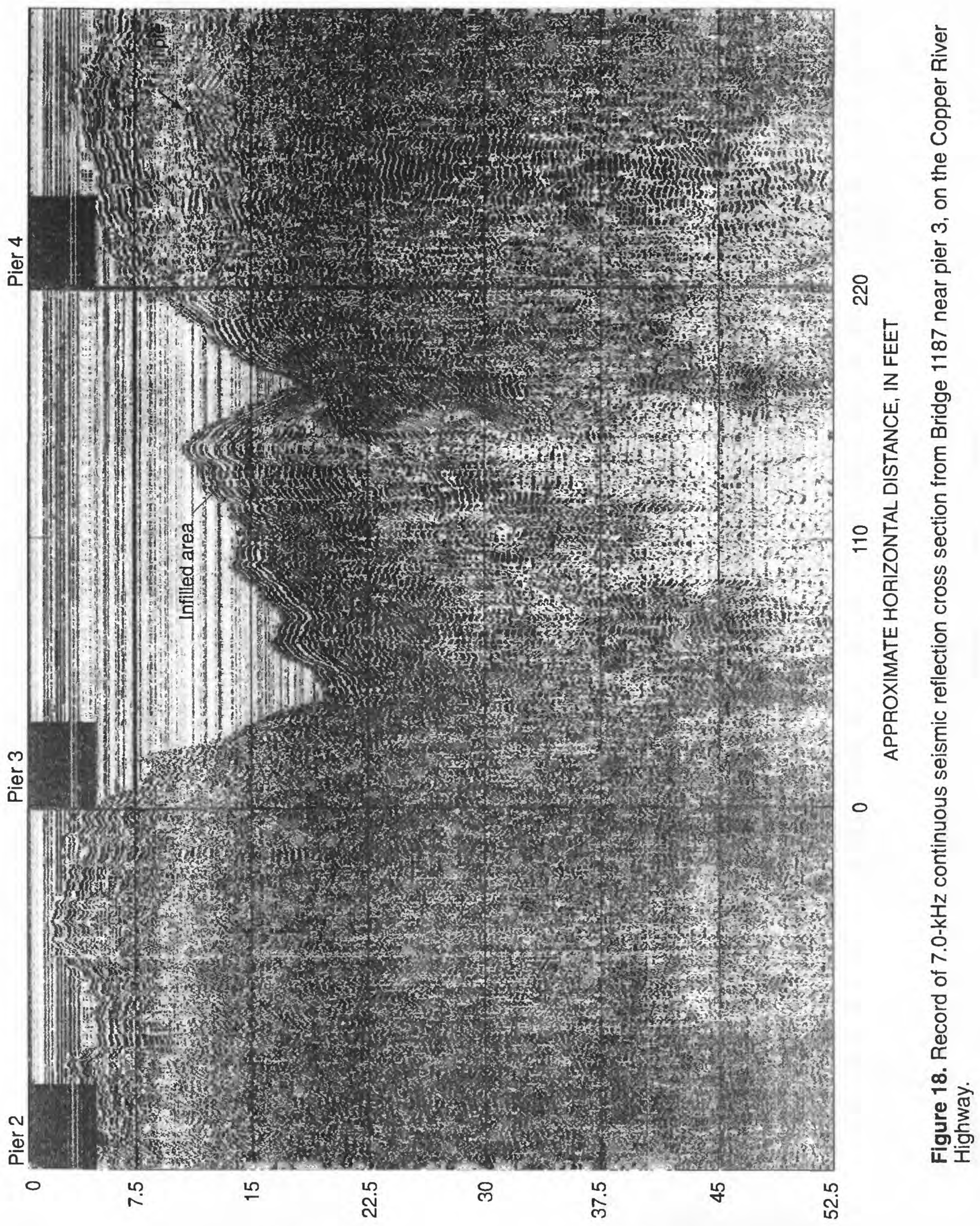




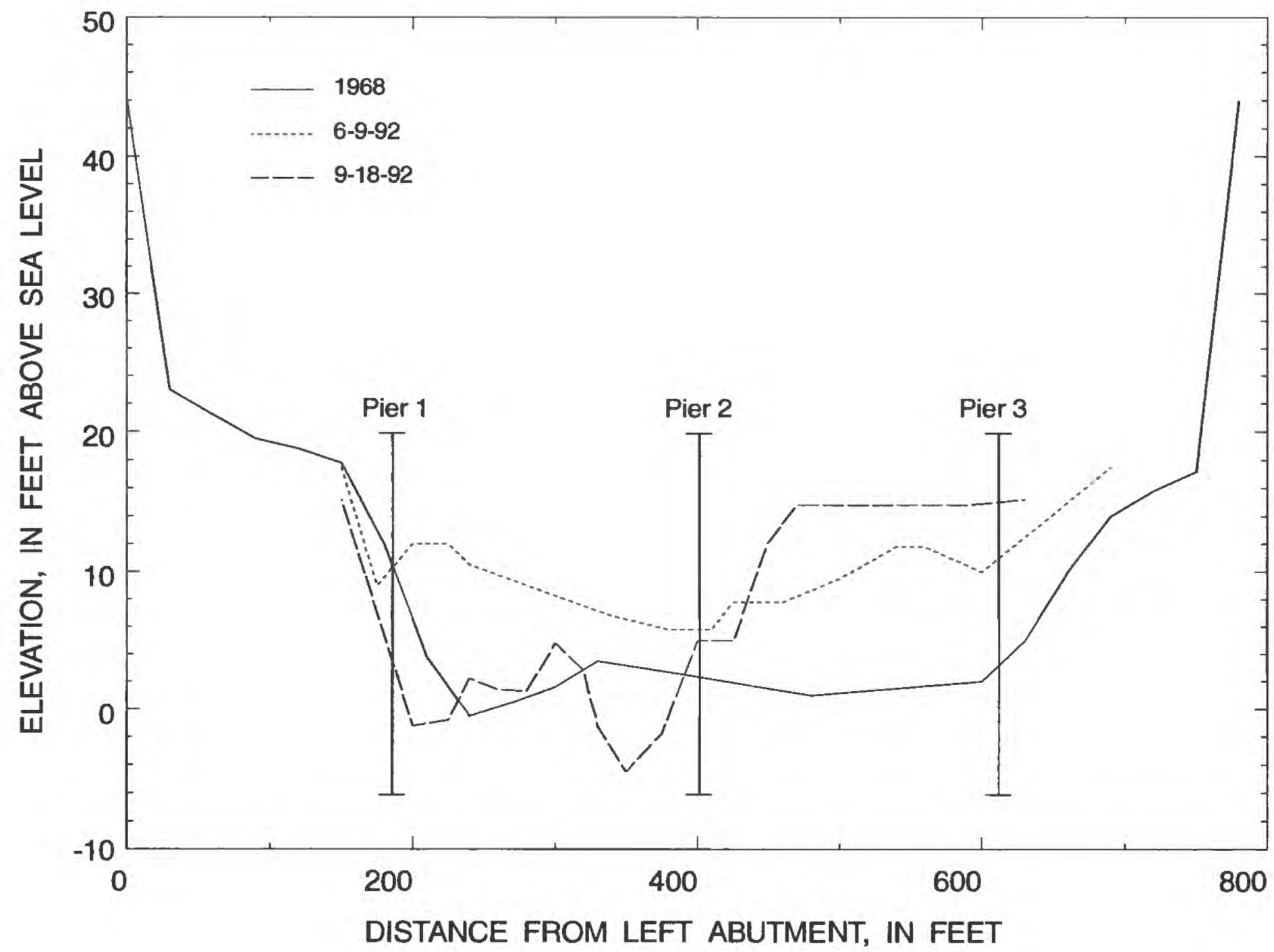

Figure 19. Cross sections of the Copper River, downstream side of Bridge 332. 

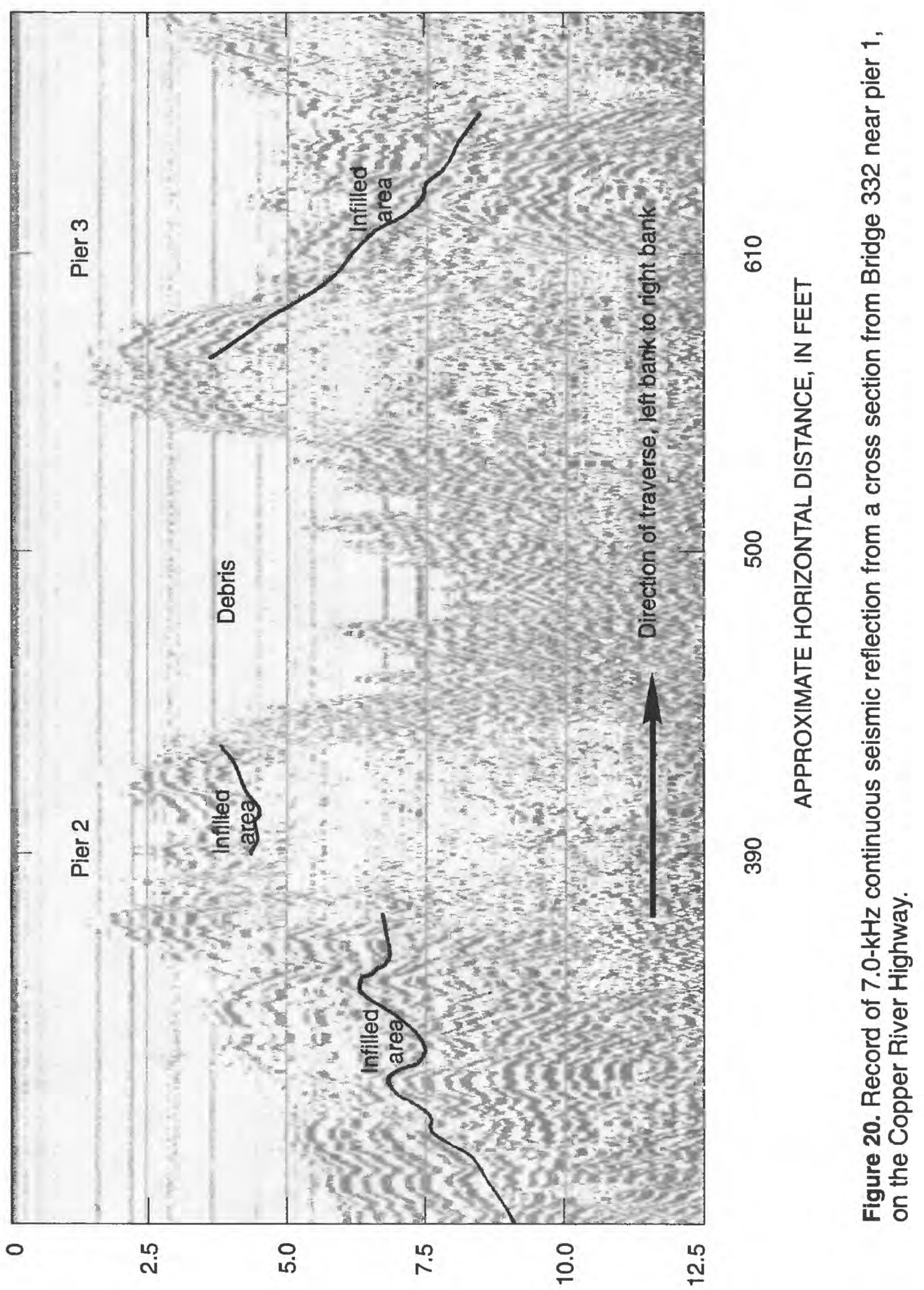

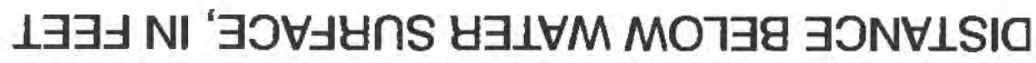




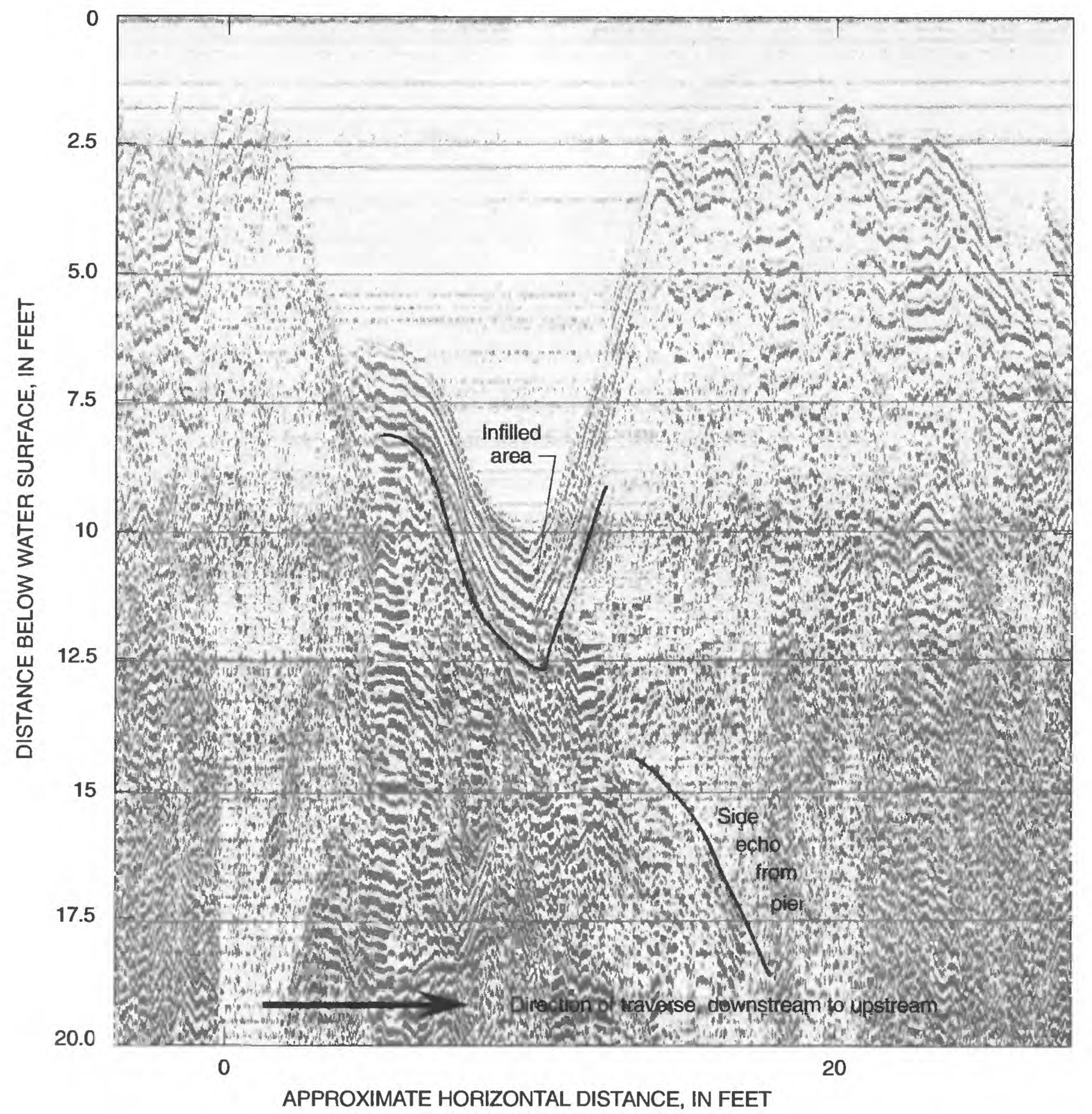

Figure 21. Record of 7.0-kHz continuous seismic reflection from longitudinal profile near pier 1 , Bridge 332, on the Copper River Highway. 


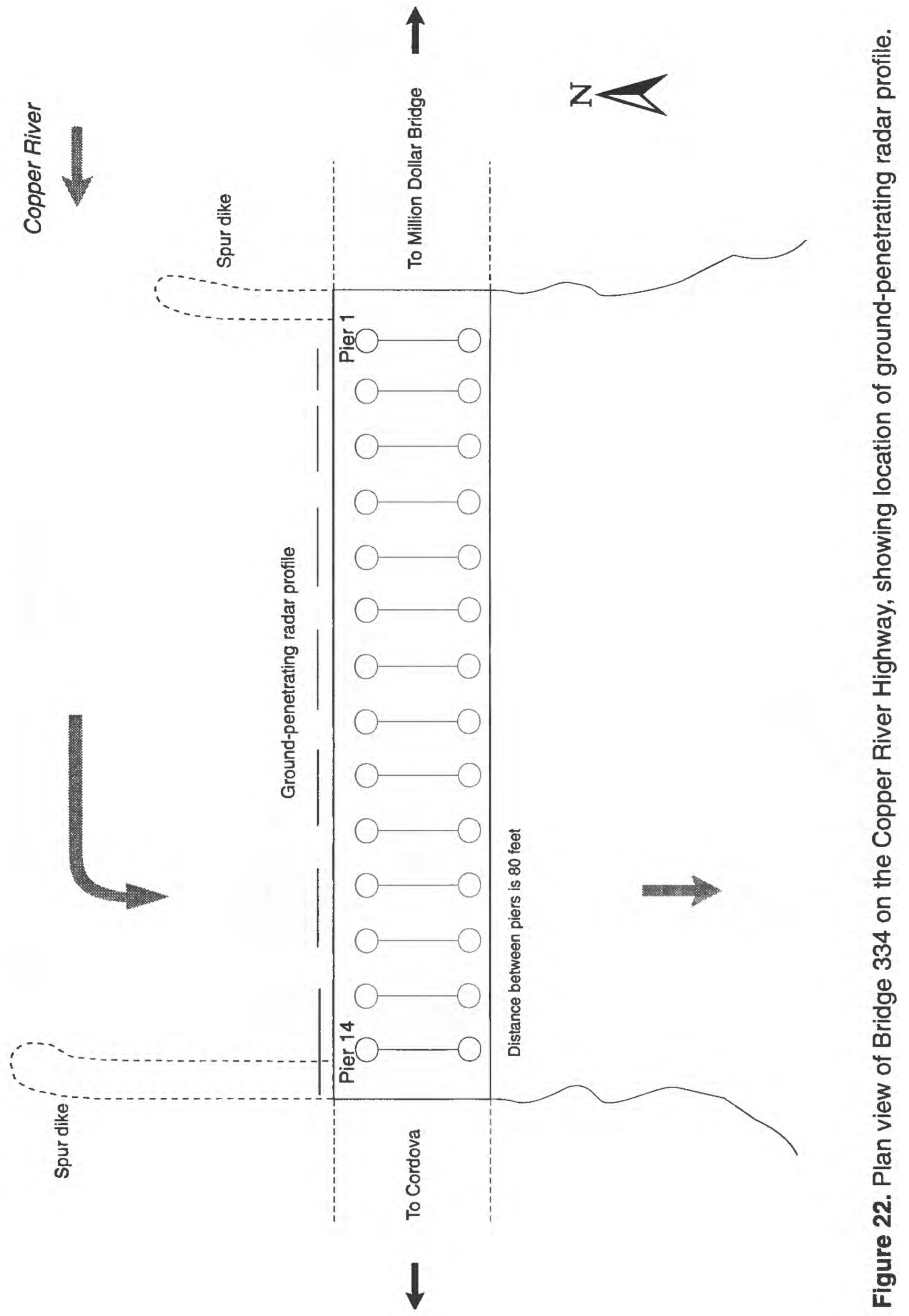




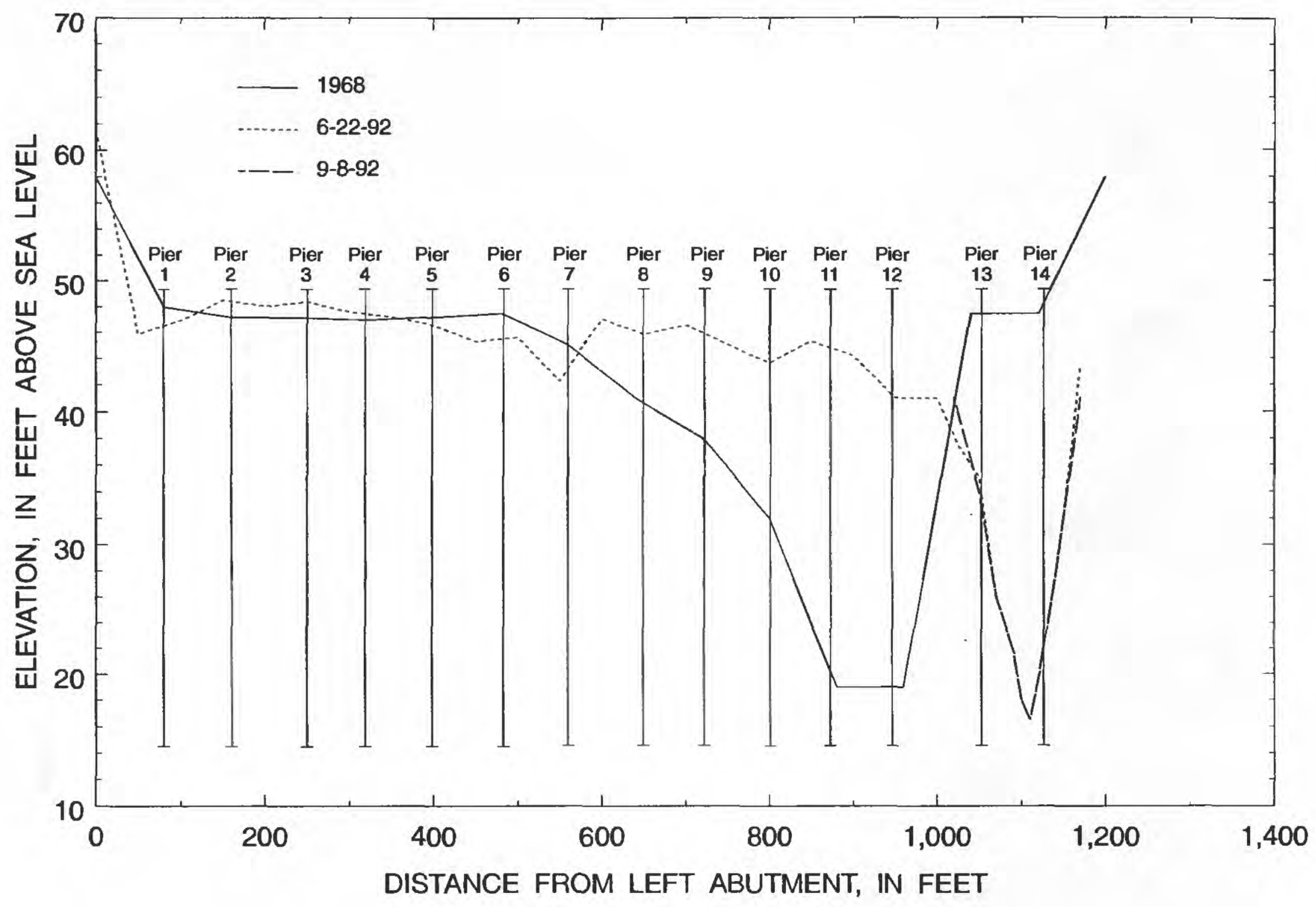

Figure 23. Cross sections of the Copper River, downstream side of Bridge 334 . 


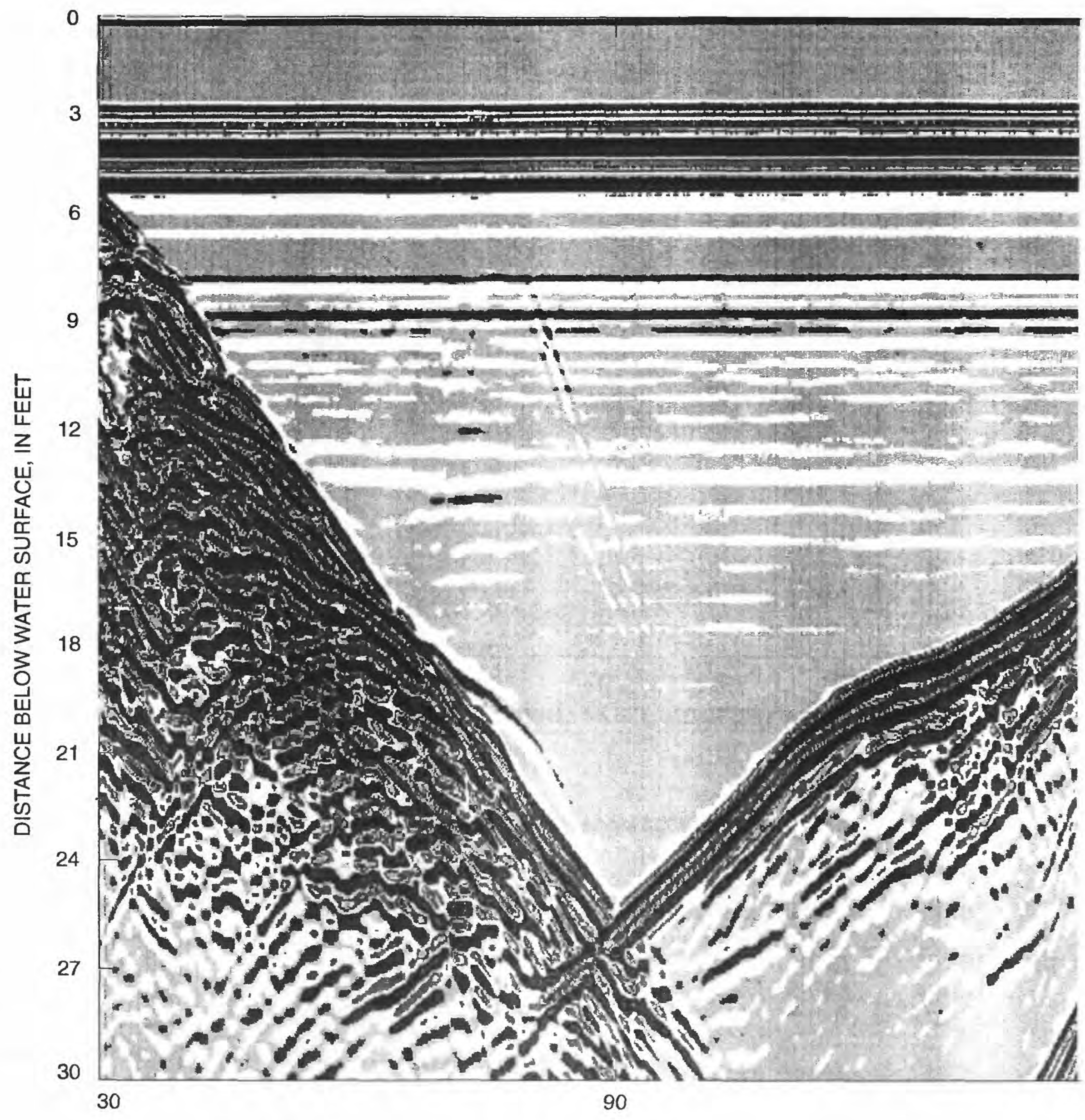

APPROXIMATE HORIZONTAL DISTANCE, IN FEET

Figure 24. Record of $100-\mathrm{mHz}$ ground-penetrating radar cross section from Bridge 334, on the Copper River Highway. 


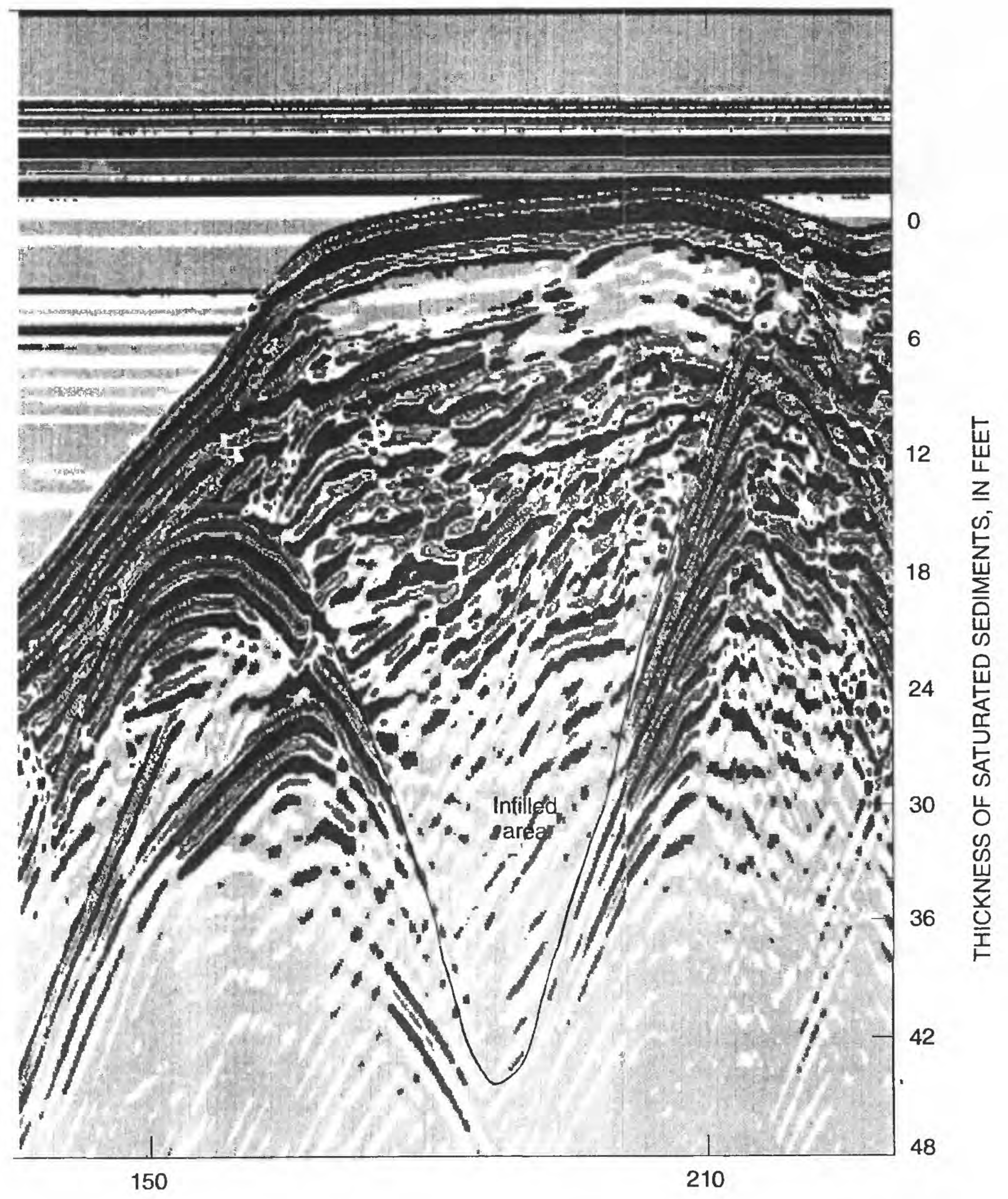



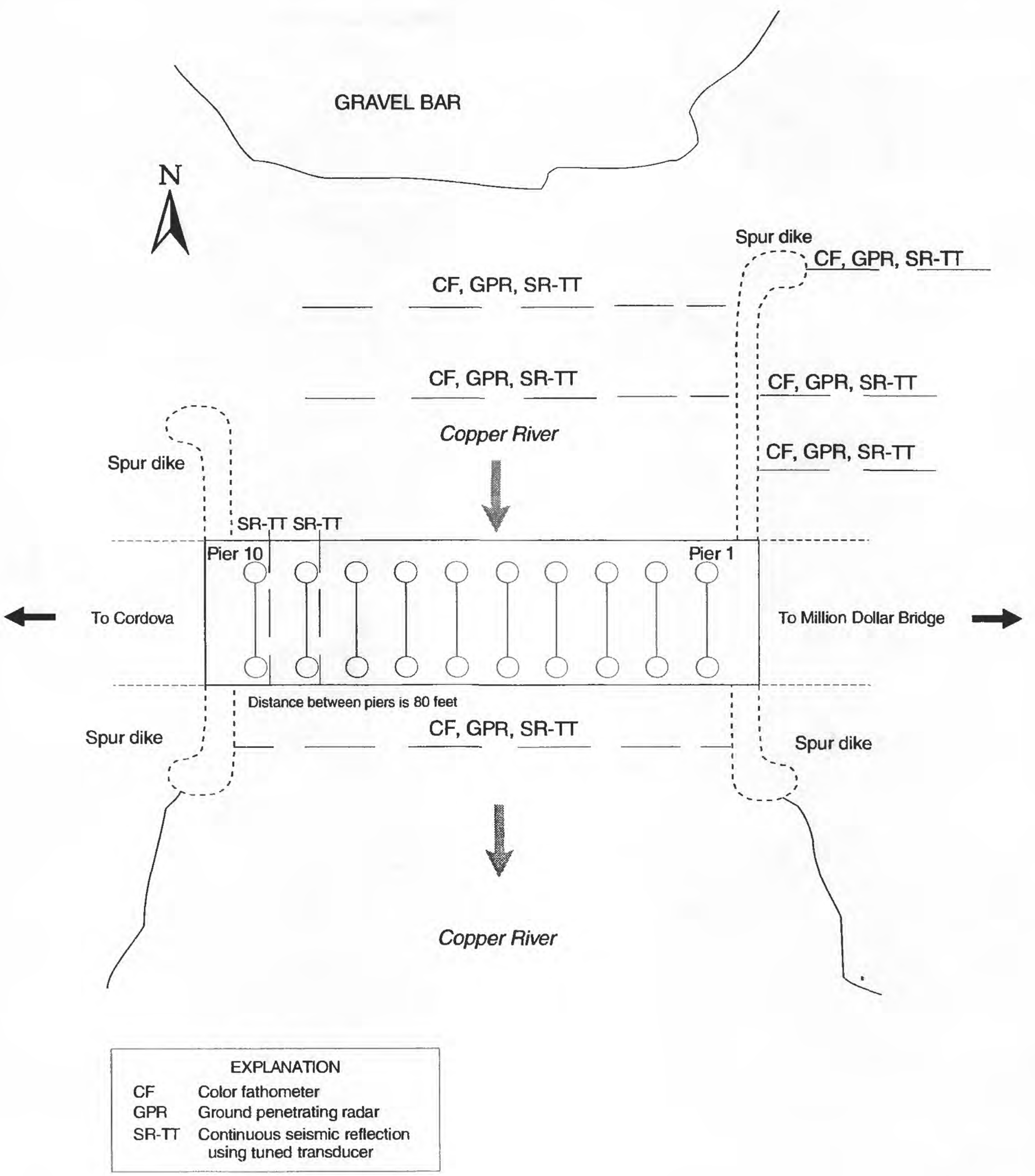

Figure 25. Plan view of Bridge 342 showing locations of geophysical profiles. 


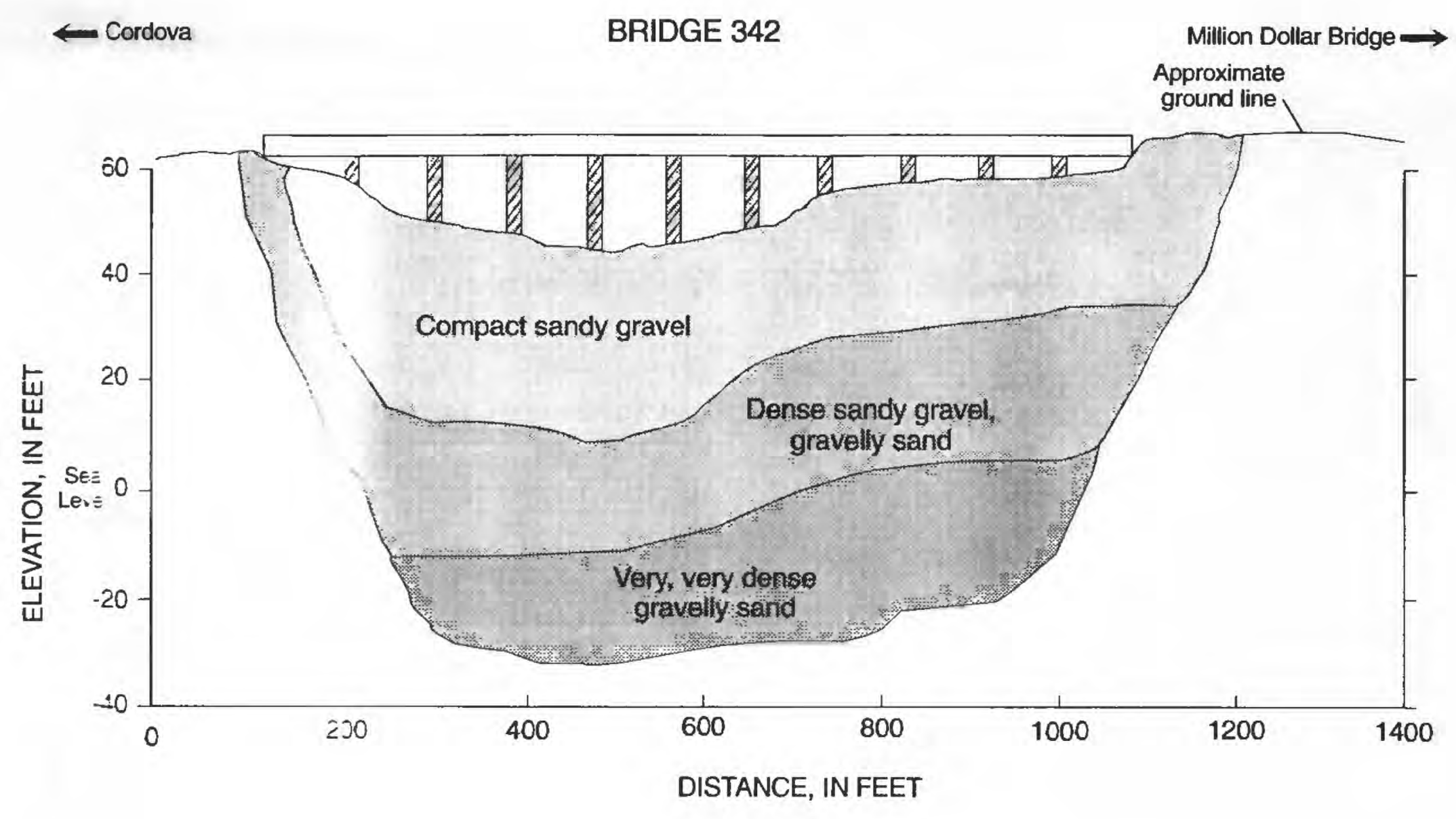

Figure 26. Generalized geologic cross section at Bridge 342 on the Copper River Highway, (modified from Alaska Department of Transportation and Public Facilities files). 


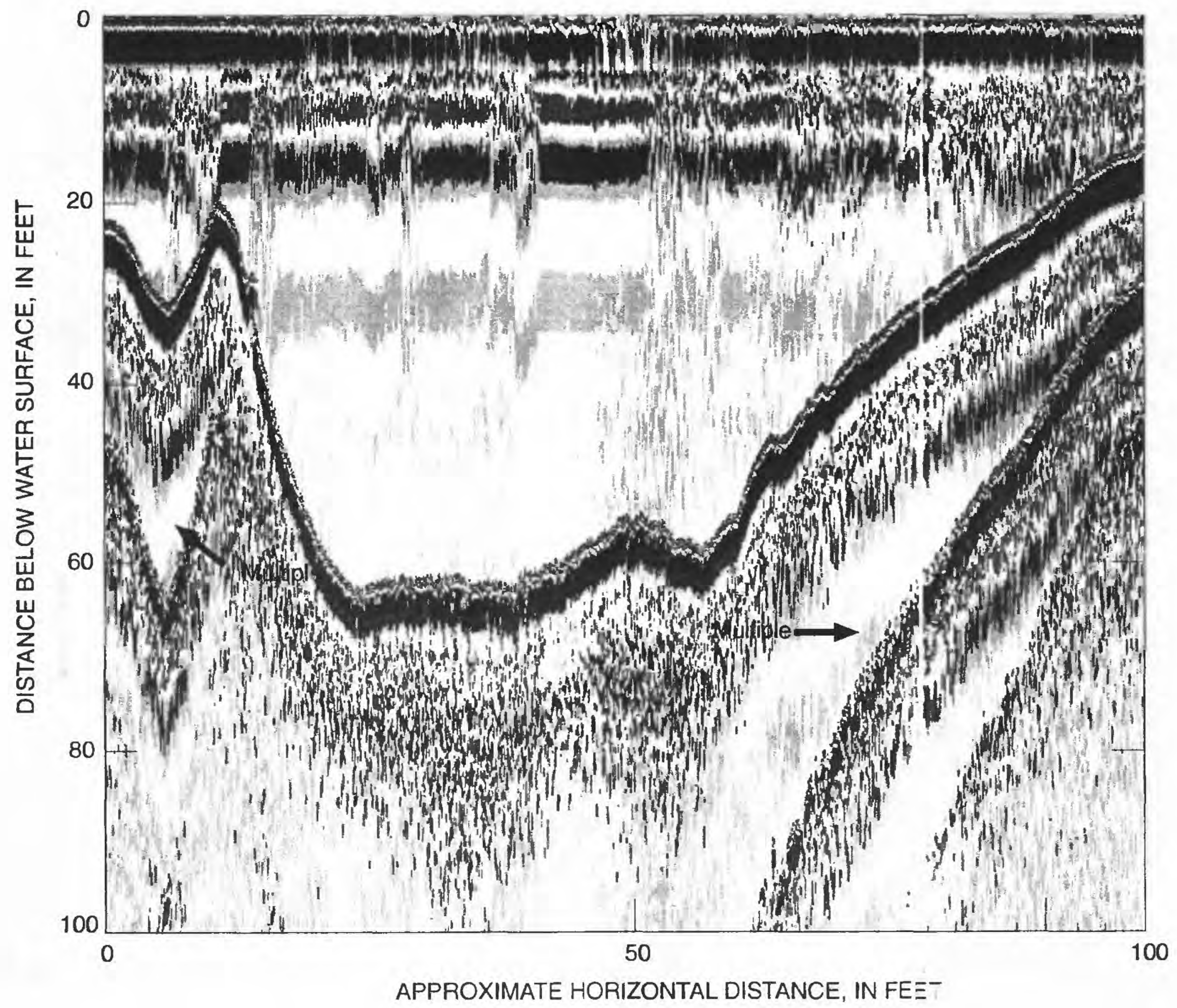

Figure 27. Color fathometer record near upstream left spur dike at Bridge $3-2$, on the Copper River Highway. 


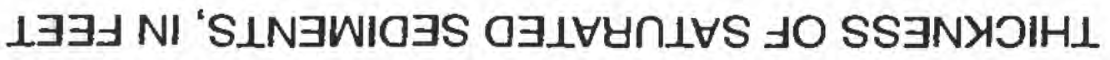

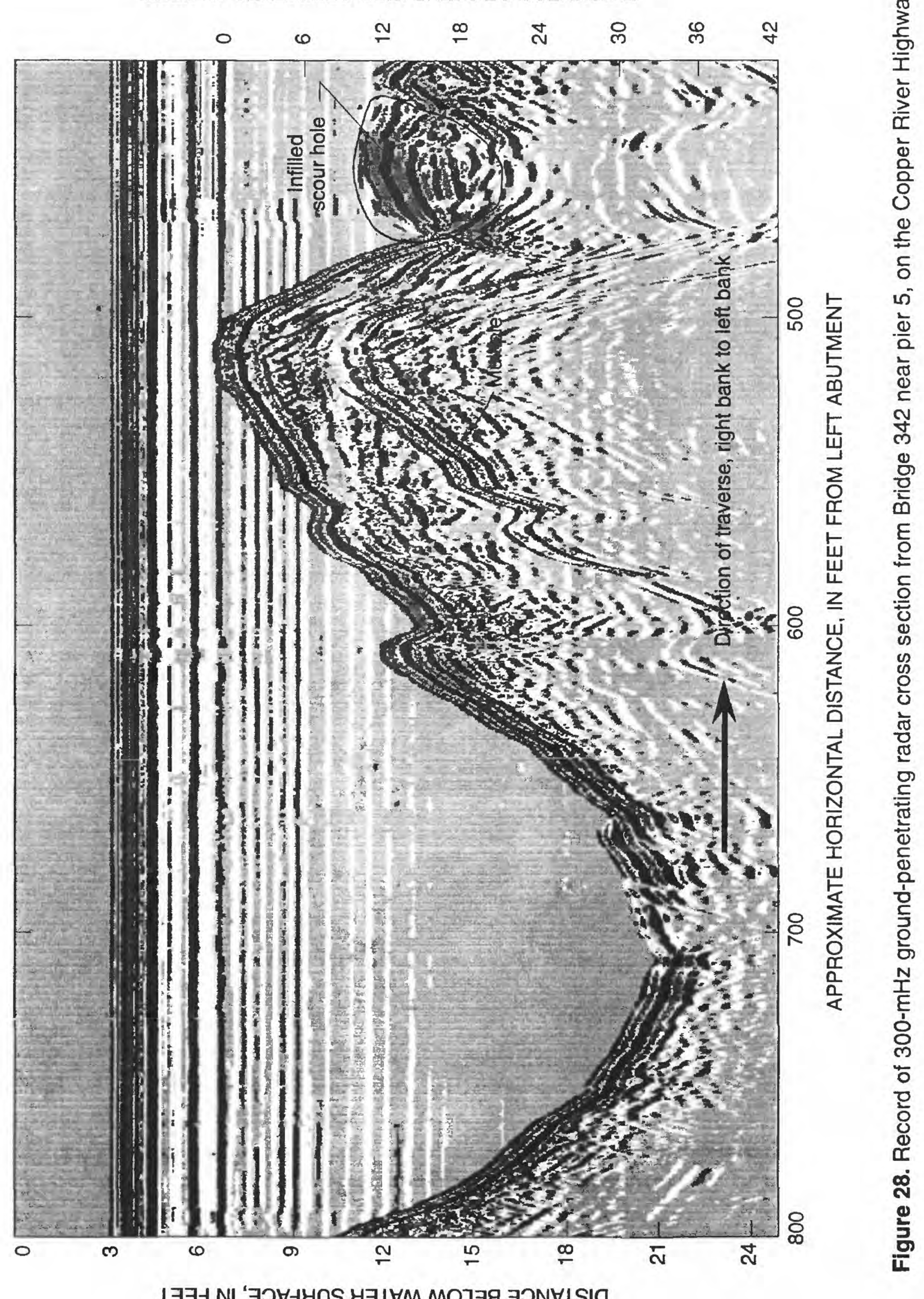




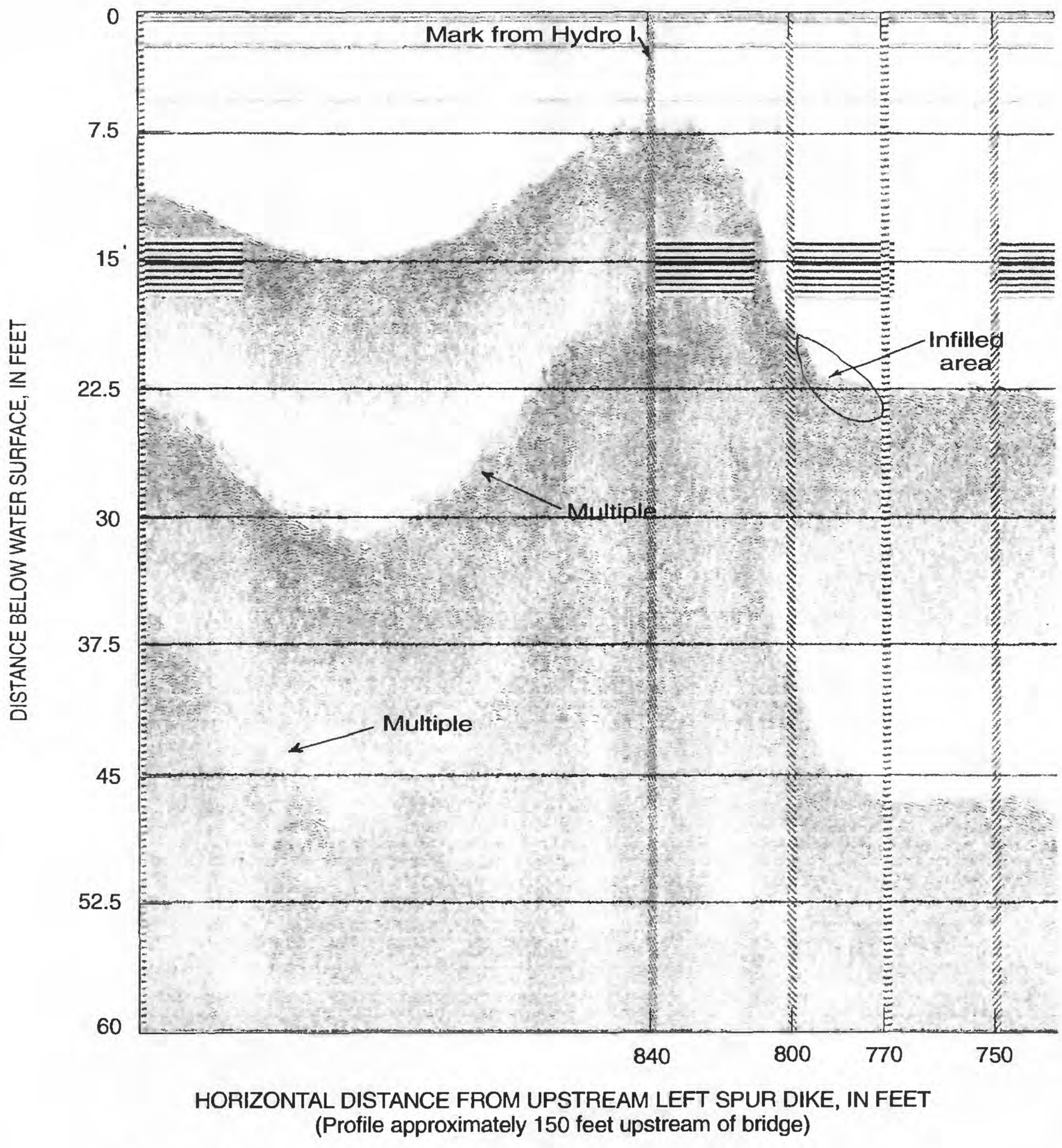

Figure 29. Record of 3.5-kHz continuous seismic reflection cross section from Bridge 342, on the Copper River Highway. 


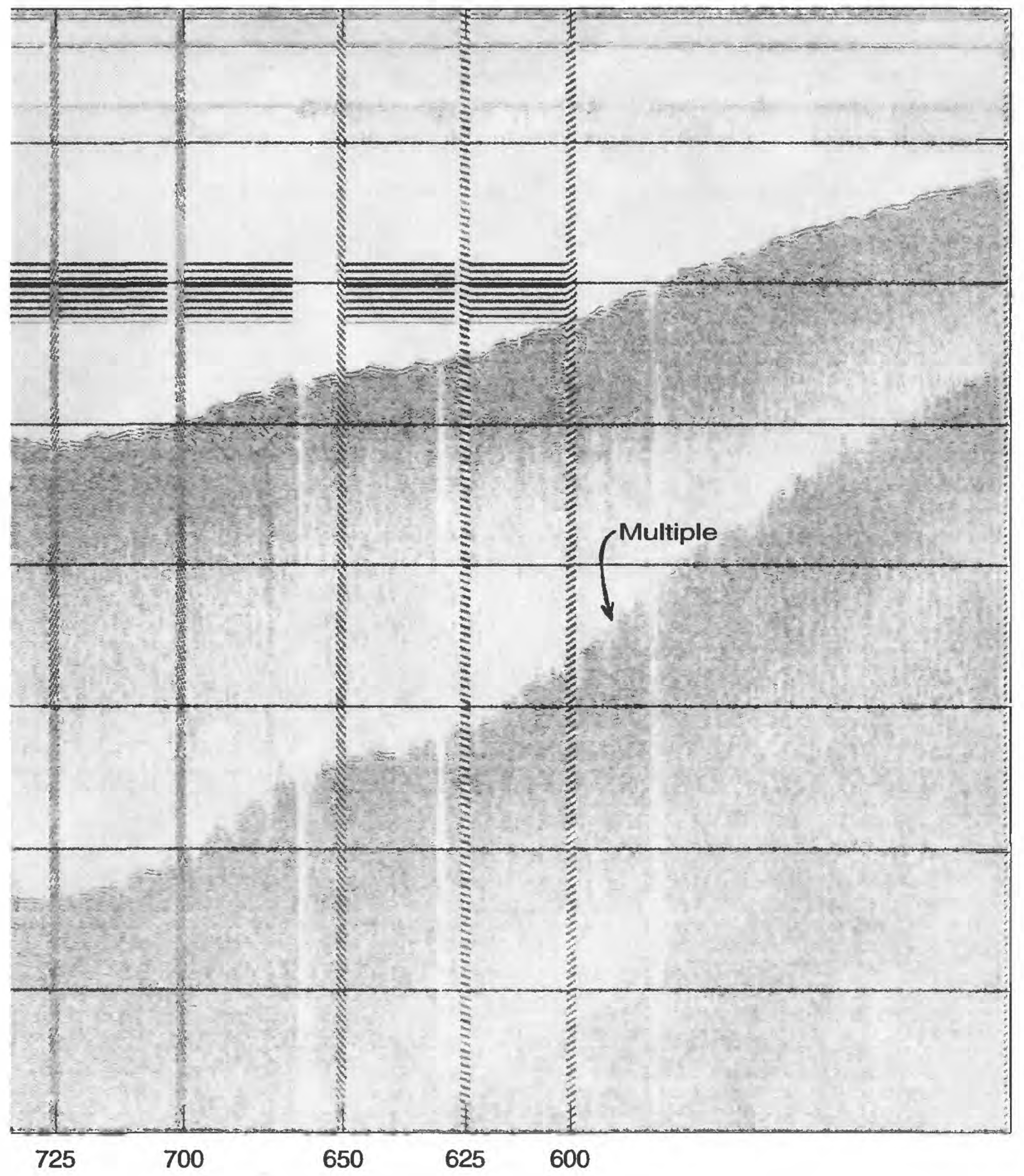

FIGURES 41 


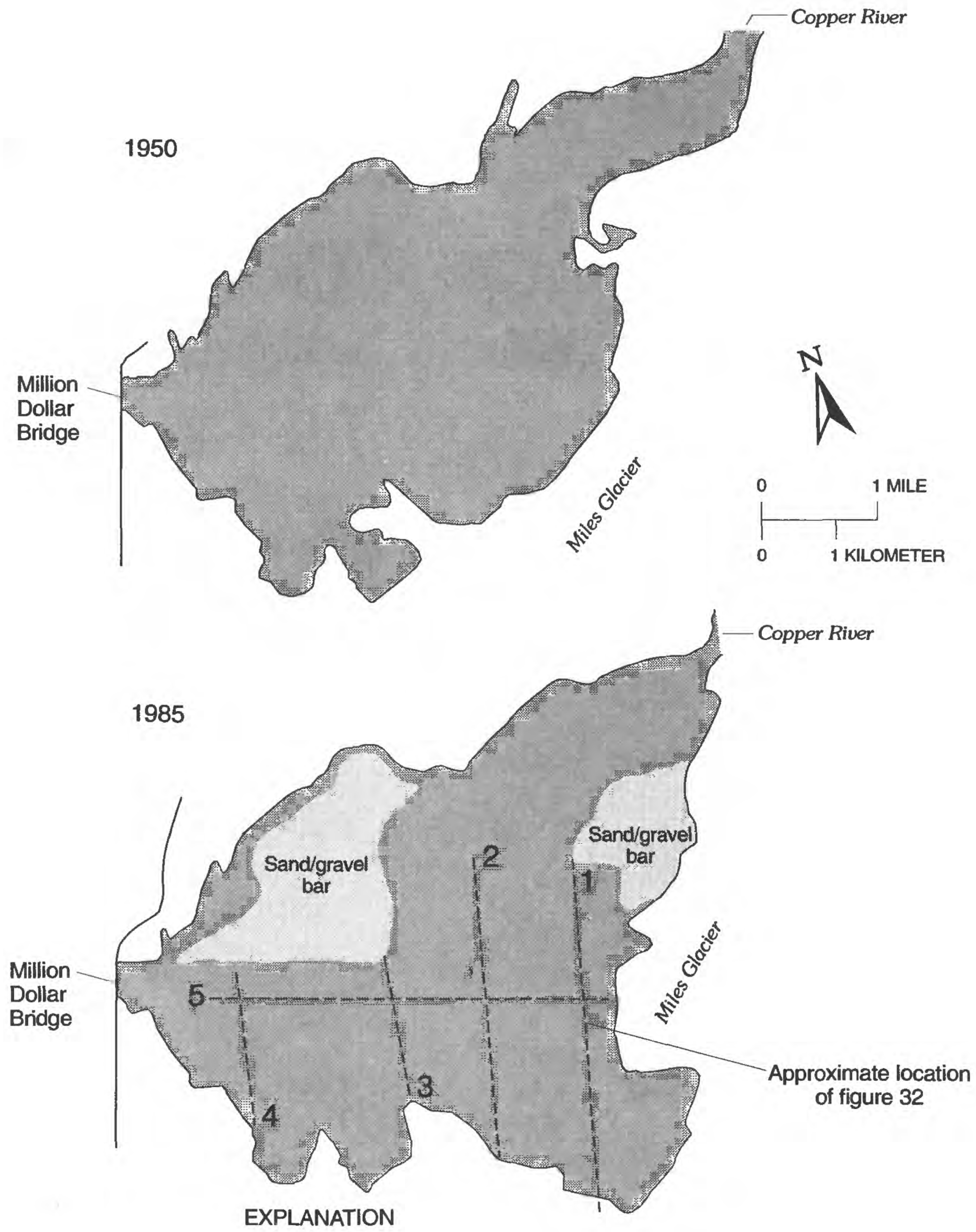

2 - Continuous seismic reflection profile line Location and number

Figure 30. Miles Lake in 1950 and 1985. 

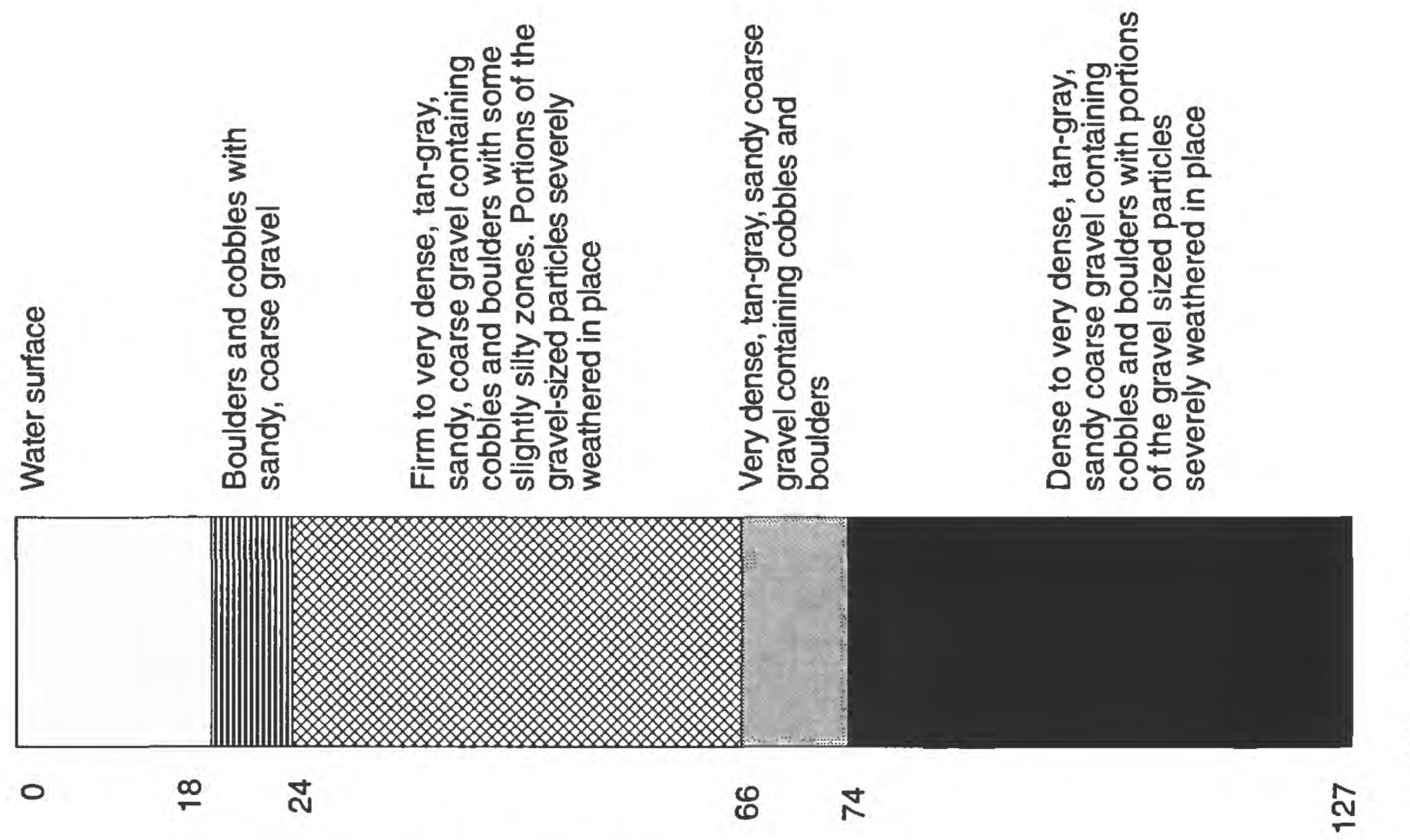

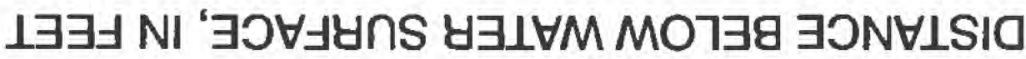

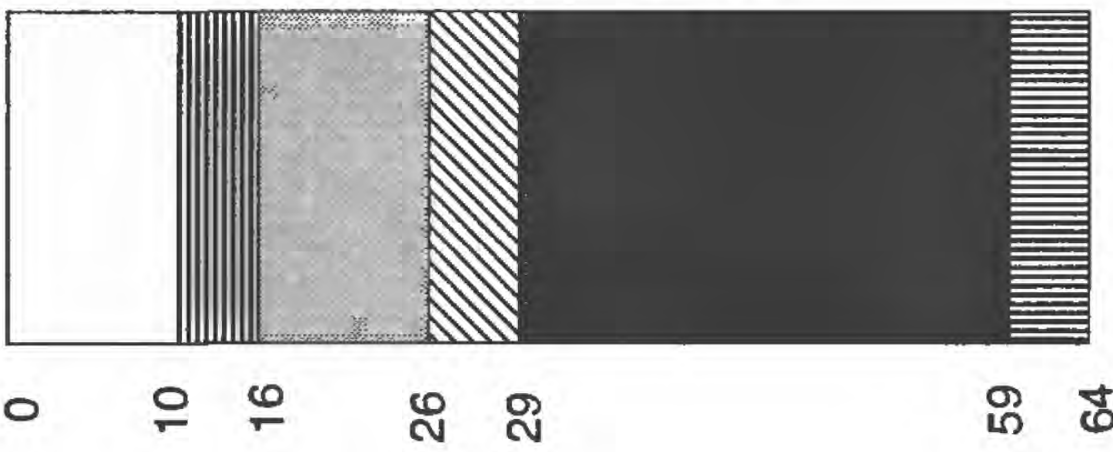

$\perp \exists \exists \exists$ NI ‘ $\exists$ $\exists \exists y \cap S$ y 


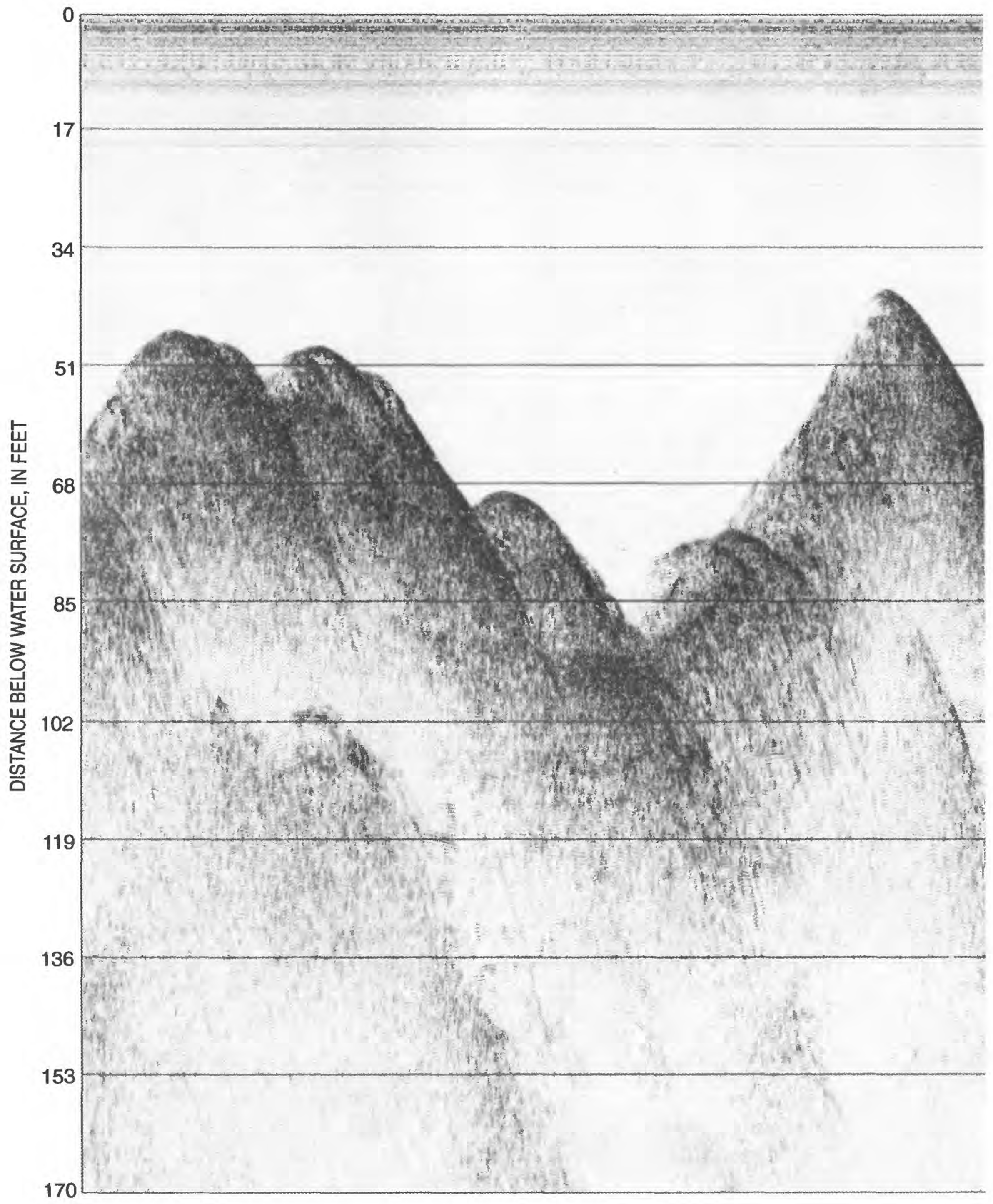

Figure 32. Record of 7.0-kHz continuous seismic reflection cross section from Profile 1 at Miles Lake.

(Approximate length of profile is one-half mile, see fig. 30 for location.) 


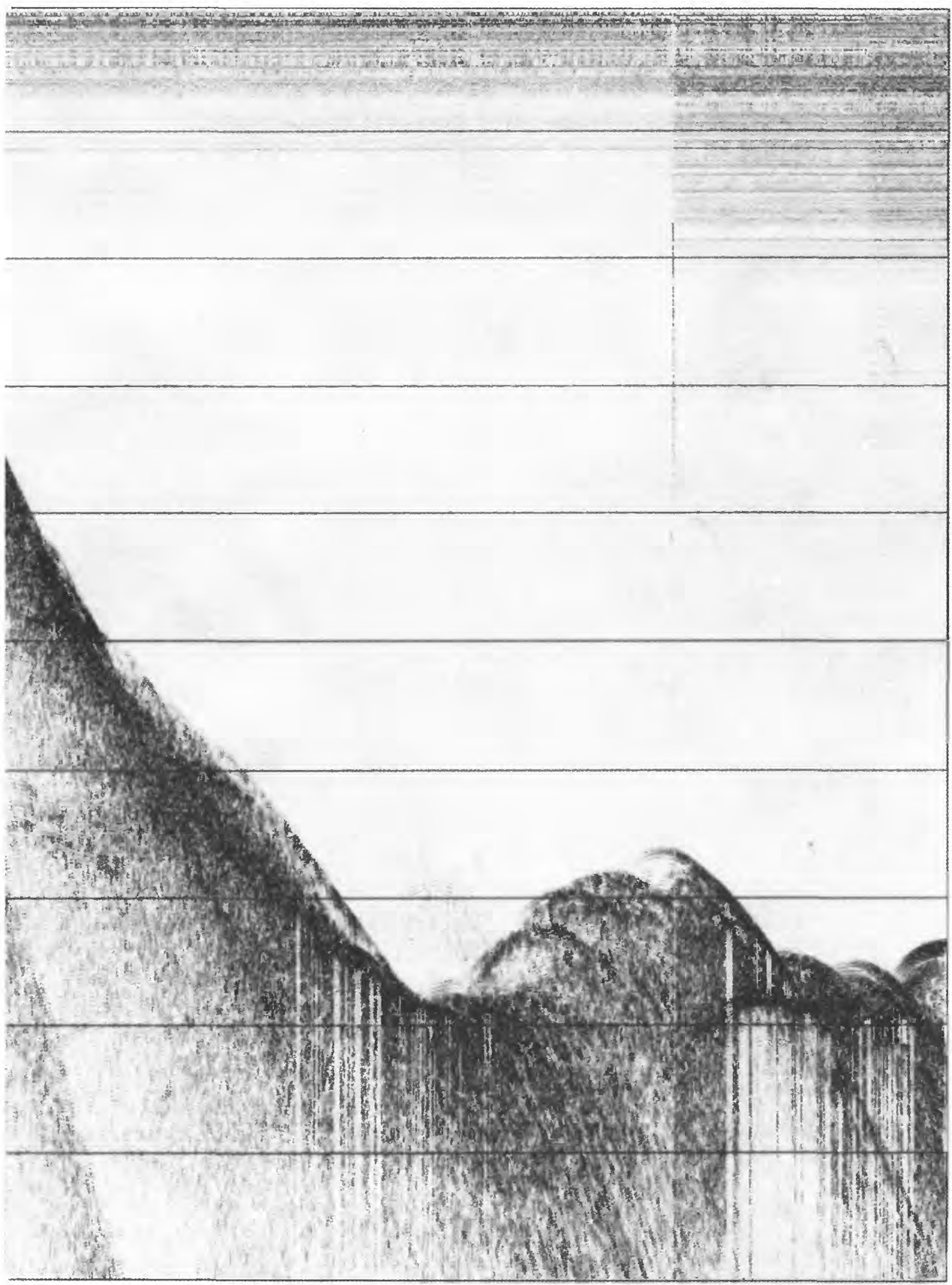




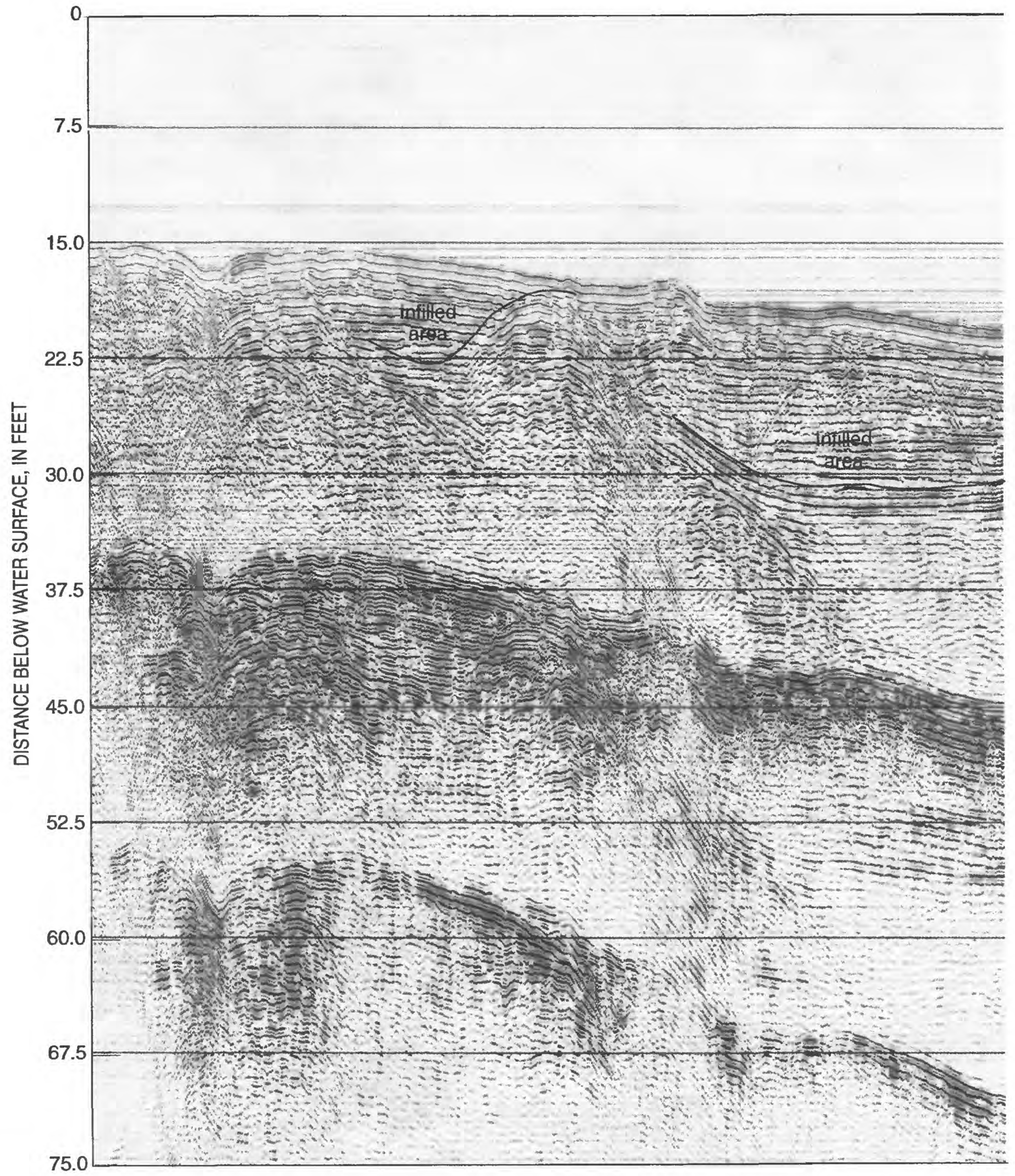

Figure 33. Record of 7.0-kHz continuous seismic reflection cross section from Profile 2 at Miles Lake. 


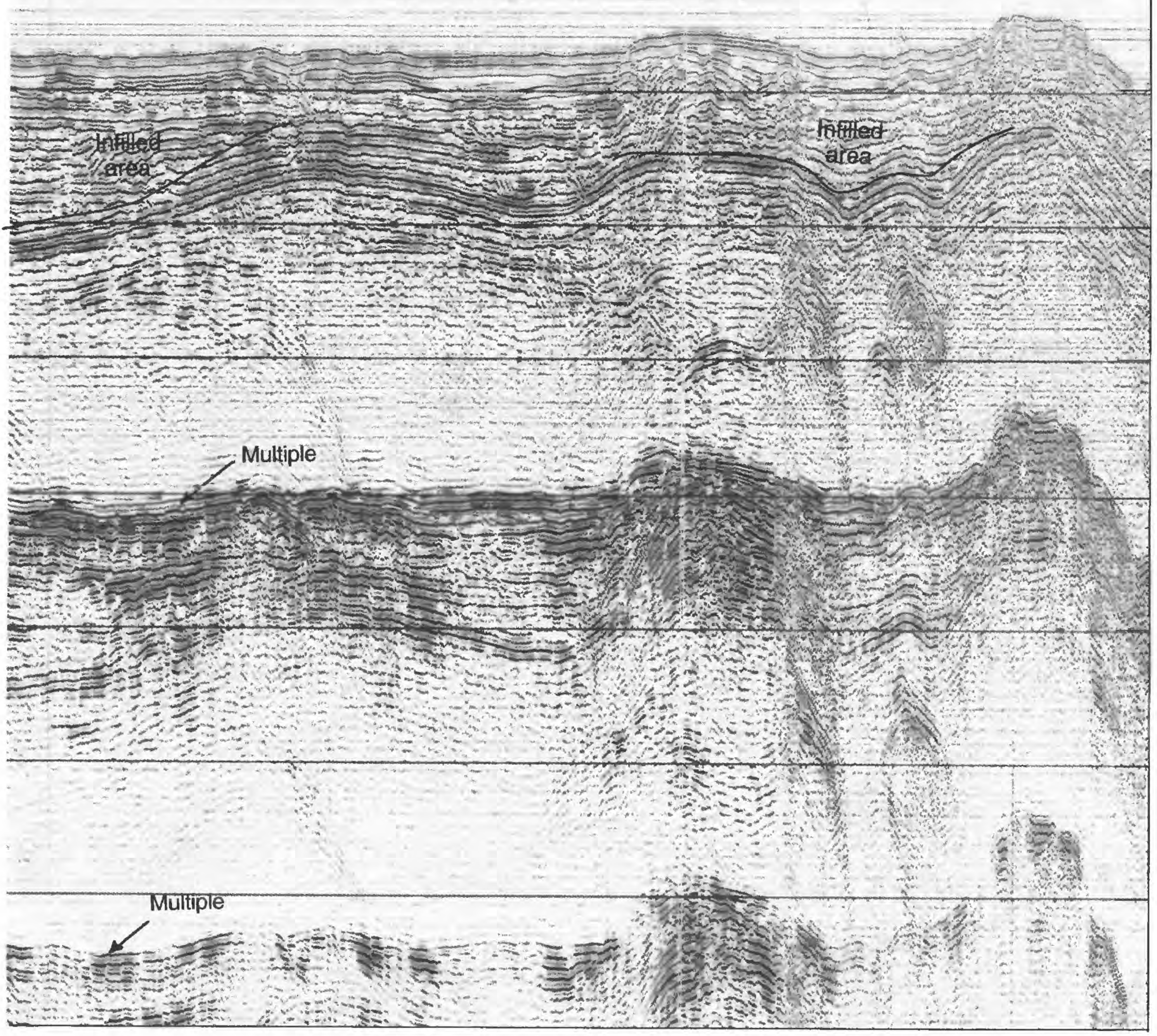

